\title{
TERESA, PATRONA DE ESPAÑA
}

\author{
POR
}

\author{
Ofelia Rey Castelao
}

Universidad de Santiago de Compostela

\section{RESUMEN}

Teresa de Ávila fue proclamada patrona de España en 1618, 1627 y 1812, pero por poco tiempo. El Apóstol Santiago, patrón tradicional, venció en las tres ocasiones. Este artículo explica brevemente los tres episodios, pero sobre todo está centrado en analizar la interpretación de los tres a través de la bibliografía que ha estudiado el tema. Se trata de ver cómo en los últimos años esas interpretaciones han elaborado complejas teorías, en línea con la nueva historia política o con la historia cultural. El artículo estudia y compara esas aportaciones.

PALABRAS CLAVE: Santos, patronos, religión, política

\section{TERESA, PATRON SAINT OF SPAIN}

\begin{abstract}
Teresa de Ávila was proclaimed Saint Patron of Spain in 1618, 1627 and 1812 , but not for long. Saint James, traditional Saint Patron, won three times. This article explains briefly these three episodes, but it is mostly focused on analyse the interpretation through the biography which has studied the topic. It is about seeing how during the last few years those interpretations have created complex theories that follow the new politic history and cultural history. The article studies and compares those contributions.
\end{abstract}

KEY WORDS: Saints, patrons, religion, politics.

$$
\begin{array}{ll}
\text { Recibido/Received } & 30-10-2014 \\
\text { Aceptado/Accepted } & \text { 10-12-2014 }
\end{array}
$$


Teresa de Ávila recibió el cetro de compatrona de España en tres ocasiones, por breve tiempo en las tres, perdiéndolo a favor de la tradición que reconocía al apóstol Santiago el Mayor como único patrón. Vista la cuestión desde este ángulo jacobeo, Teresa era la usurpadora y Santiago el agraviado, pero en realidad, ambos fueron manipulados en beneficio de causas ajenas. En las discusiones sobre el patronato, dos figuras pacíficas, un discípulo de Cristo muerto en el martirio y una mística reformadora y escritora, fueron situados en bandos opuestos en una lucha entre la espada y la rueca, las armas y las letras, la guerra y la paz, antiguos y modernos, conservadores y liberales, hasta el punto de que apenas pueden reconocerse en medio del entramado mítico construido en su entorno desde el siglo XVII hasta ahora.

Del mismo modo que Teresa de Ávila perdió el patronato, su condición de patrona está menos estudiada que la de Santiago. Los centenarios a celebrar desde 2014 a 2022 contribuirán a su estudio -y a su magnificación-, pero el Apóstol se beneficia de las celebraciones encadenadas por los años santos y de la «invención» de otras, útiles a intereses políticos y turísticos, aprovechados por eruditos locales o historiadores «sensibles» a esas consideraciones, pero no nos detendremos en esto porque no suelen ser investigadores profesionales, aunque afectan, y mucho, a la divulgación y contribuyen a la perpetuación de mitos y leyendas. Así pues, estas páginas están orientadas solo a analizar una intensa polémica surgida en el contexto del Barroco castellano sobre la primacía en el patronato. No haremos un relato exhaustivo de los hechos por ser muy conocidos, sino que revisaremos lo escrito al respecto para ver cómo se ha observado desde diferentes ángulos.

\section{EL PRIMER PATRONATO: 1618}

Santa Teresa ha reemplazado ya a las diosas medievales, las eulalias, leocadias, etcétera, porque fue proclamada por el bobo de Felipe III patrona de España, de la misma manera que Juno lo era de Cartago, y Minerva, de Atenas; Santiago, sin embargo, siguió siendo el Hércules masculino... e incluso en nuestros días, las Cortes de Cádiz, o sea, la prudencia colectiva de España, se volvieron en la hora de la verdad a ella. ${ }^{1}$

Esa cáustica síntesis de Richard Ford (1844) pone un punto ácido al hecho de que en 1618 Felipe III proclamó a Teresa de Ávila como compañera de Santiago en el patronato, desatando una polémica con complejas implicaciones. ¿Pero era el Apóstol «patrón de España»? La tradición y las crónicas fijaban el origen de ese rango en la batalla de Clavijo de 834, victoria del rey Ramiro I sobre los

${ }^{1}$ Ford, R. 2008. Manual para viajeros por España y lectores en casa: 146, 3, Madrid: Turner Publications.

Hispania Sacra, LXVII

136, julio-diciembre 2015, 531-573 ISSN: 0018-215X, doi: 10.3989/hs.2015.016 
musulmanes conseguida con la intervención milagrosa de Santiago; la legendaria ocasión se narra en el llamado Pergamino del Voto de Santiago en el que rey concedía al Apóstol el pago anual de la renta de ese nombre. Pero el patronato era una construcción medieval de mayor peso político que religioso, bien estudiada desde los años ochenta del siglo xx por una interesante bibliografía -A. Sicart, F. López Alsina o K. Herbers- ${ }^{2}$ en la que se subraya que el interés político en la protección del Apóstol sobre el rey surgió en el siglo IX, que la imagen militar del Santiago caballero es tardía - del siglo XII- y que tuvo que competir con otros protectores (San Isidoro, la Virgen), al ritmo de la Reconquista y de las devociones de los reyes, decayendo en el xIV. Sin embargo, los Reyes Católicos en 1486 al validar la documentación de la catedral compostelana -incluido el privilegio del Voto- y al encomendar al Apóstol la conquista de Granada, lo revitalizaron, algo que captó la erudición jacobea tradicional, ${ }^{3}$ ya que desde entonces sí se podría decir que Santiago era patrono, y así se mantuvo durante el siglo XVI.

Hasta la novedad del compatronato, Felipe III sostuvo una buena relación con la catedral compostelana: ${ }^{4}$ en 1614 nombró arzobispo de Santiago a don Juan Beltrán de Guevara, autor una defensa de la tradición jacobea; vendió al cabildo y al arzobispo por una gran suma, las protectorías del Voto de Santiago, y aquellas instituciones colaboraron con dinero en la canonización de Teresa. Pero el 15 de julio de 1617 una comisión de cardenales había decidido en Roma que la beata podía ser canonizada y el 24 de octubre, el general de los carmelitas descalzos, Luis de San Jerónimo, propuso a las Cortes de Castilla su declaración como co-patrona, alegando sus libros y doctrina, su reforma y su ejemplo de vida, lo que se aceptó sin gran discusión y el 4 de agosto de 1618 Felipe III ordenó a las autoridades civiles aplicar la novedad y comunicó a las diócesis que se hiciera efectiva: una muestra de entusiasmo con la beatificación por parte de una monarquía en crisis, situaba a Teresa al lado del Apóstol, en teoría sin perjudicarlo, pero rompiendo una tradición antigua, por lo que pronto surgieron

${ }^{2}$ Sicart, A. 1982. «La iconografía del Santiago ecuestre en la Edad media», Compostellanum: 11. Sicart, A. 1985. «La figura de Santiago en los textos medievales», en G. Scalia, Il Pellegrinaggio a Santiago de Compostela e la letteratura jacopea: 271. Perugia: Centro It. di Studi Compostellani; López Alsina, F. 1999. «Cabeza de oro refulgente de España: los orígenes del patronato jacobeo sobre el Reino asturiano», en J.I. Ruiz de la Peña, Las peregrinaciones a San Salvador de Oviedo en la Edad Media: 27. Oviedo: C. de Educación. Herbers, K. 1999. Política y veneración de los santos en la Península Ibérica. Desarrollo del Santiago político, Poio: Fund. Cult. Rutas del Románico. Nieto Alcalde, V. y García Morales, M.V. 2004. «Santiago y la monarquía española: orígenes de un mito de Estado», en J. M. García Iglesias (coord.), Santiago y la monarquía de España (1504-1788): 34. Madrid: SECC. Rucquoi, A. 2007. «Clavijo: Saint Jacques Matamore», Compostelle. Cahiers d'Études 10: 48-58.

${ }^{3}$ Carro García, J. 1947. «Santiago Apóstol. Patrón de las Españas», Spes 151: 14-16.

${ }^{4}$ Rey Castelao, O. 2007-8. «La disputa del patronazgo de la Monarquía: ¿Santiago o Santa Teresa?», en J. Martínez Millán y M.A. Visceglia (edts.), La Monarquía de Felipe III: la Casa del Rey: 227-246, I. Madrid: Fund. Mapfre. 
reacciones contrarias. La primera procedió de la iglesia catedral de Compostela, la más perjudicada, que encargó al canónigo doctoral e inquisidor de Galicia, Benito Méndez de Parga, una alegatio iuris, publicada en 1618, sobre a si el rey, estando en Cortes, podía tomar y elegir patrón a algún santo; si era bueno darle compañía al existente y si el reino puede obligar al estado eclesiástico a rezar al nuevo patrón. Ese texto fue respondido por el jurista de las Cortes don Francisco de La Cueva y Silva justificando como suficiente la elección de Teresa por las Cortes, con consentimiento del rey, texto retirado por la Inquisición -según una carta de Bernardo Alderete de 13-XI-18-, junto con otros como Acerca del patronato... a quien eligieron los reyes en sus Cortes por patrona donde se trata si Teresa podía ser patrona siendo beata, si los procuradores podían intervenir en asunto eclesiástico «para el cual las Cortes no tienen facultad» y si el patronato era absoluto o parcial. ${ }^{5}$ Así pues, la polémica se abría como un pleito a dos partes, con sus abogados y sus alegatos jurídicos.

La Corona no previó la reacción de otras instituciones vinculadas a la tradición de la predicación de Santiago, ni que el tema se inflara en las imprentas, en textos circunstanciales y oportunistas que dieron notoriedad efímera a autores menores. A efectos prácticos, lo más importante fue lo primero, ya que muchos prelados condicionaron su respuesta a que el papa aprobase la proclamación de Teresa, y Santiago encontró apoyos tan significativos como el de arzobispo de Sevilla, don Pedro de Castro, que lo había sido de Granada y que era el fundador de la Colegiata del Sacromonte, no en vano, según los famosos Libros Plúmbeos, Santiago había implantado en Granada las raíces del cristianismo peninsular. ${ }^{6}$ Don Pedro escribió un memorial criticando la novedad de un patronato elegido por seglares y la no menor de que Teresa fuese sólo una beata, inferior a «santos de España» y a la que no se podía rezar con la solemnidad debida a los patronos que marcaba el breviario romano; además, encargó otro al benedictino fray Antonio Pérez dirigido al rey. ${ }^{7}$ No fueron los únicos textos projacobeos, entre los que no faltaron ayudas de doble filo como la del jesuita falsario Jerónimo Román de la Higuera. Volveremos sobre esto.

Más allá de las presiones de unos y otros, en la retractación de setiembre de 1618 los procuradores de las Cortes de Castilla revelan su preocupación por haberse excedido en su autoridad al otorgar ritos a una beata, ${ }^{8}$ y como solución

\footnotetext{
${ }^{5}$ Rodríguez, I. 1972. Santa Teresa de Jesús y la espiritualidad española: 109. Madrid: CSIC.

${ }^{6}$ Barrios Aguilera, M. y García-Arenal, M. (eds.). 2008. ¿La Historia inventada? Los Libros Plúmbeos y el legado sacromontano, Granada: Universidad.

${ }^{7}$ Santos Fernández, C. 2008. «Pesquisas realizadas en Sevilla para identificar al autor y al impresor de la contradicción a la carta del arzobispo Pedro de Castro en defensa del Patronato de Santiago», Historia, instituciones, documentos 35: 321-353.

${ }^{8}$ Thompson, I.A.A. 2008. «La cuestión de la autoridad en la controversia sobre el Patronato de Santa Teresa de Jesús», en J. Aranda Pérez y J.D. Rodrigues, De Re publica Hispaniae: 293-320. Madrid: Sílex.
} 
a la polémica, en noviembre Felipe III ordenó suspender las gestiones ante el papado, quizá a la espera de la canonización de Teresa. Al ser una suspensión que no un cierre, se publicaron todavía más textos polémicos. En 1620, un anónimo consideraba justo que Teresa fuese admitida como patrona ya que no perjudicaba a Santiago; sin negar la conveniencia de elegir a Teresa, una Información escrita por M.P. de Azpeitia de 1620 cuestionaba la capacidad de las Cortes para intervenir, reclamando que fueran los obispos por afectar a materias espirituales, y corresponder a la Iglesia la materia del compatronato; en el otro extremo, el jesuita Gaspar Sánchez, publicó un tratado sobre el elenco jacobeo completo, incluida la fundación de El Pilar de Zaragoza, tema con sus propias implicaciones. En 1621 murió Felipe III y en 1622 Gregorio XV canonizó a Teresa, junto con otros santos igual de distantes que ella -ejemplo del movimiento místico y de la intimidad espiritual- de la imagen militar del Apóstol, de modo que el debate parecía cerrado.

La bibliografía ha tendido a hacer complejas teorías de la elección de Teresa, a pesar de su efímero éxito, pero en nuestra opinión fue una maniobra para impulsarla hacia la santidad y sobre todo un episodio más de la crisis del culto al Apóstol. Así lo reflejó Cervantes en El Quijote, en la escena de los labradores que cargan un retablo con la imagen del Patrón de las Españas; la ironía cervantina no es asunto baladí -fue estudiado por E. González López y M. Moner-, ${ }^{9}$ no en vano D. Péricard-Méa atribuye a Cervantes el término matamoros asociado a Santiago, muestra de la decadencia de su prestigio y de su escasa utilidad de su ayuda después de la expulsión de los moriscos. ${ }^{10}$

De un modo u otro, Cervantes atinaba. En 1621, Diego de Saavedra Fajardo comunicaba la obtención en Roma del rito semidoble de Santiago, lo que suavizaba un largo desacuerdo entre el papado y la monarquía hispánica sobre el reconocimiento litúrgico de la tradición jacobea, pero en esos mismos años los elementos de esa tradición se cuestionaban en el seno de la monarquía, desde la presencia de los restos de Santiago en Compostela a la autenticidad del pergamino del Voto, pilares del patronato del Apóstol. Con base en ese pergamino, los campesinos de la mayor parte de la Corona de Castilla pagaban cada año la renta del Voto, en medio de una enorme resistencia motivada por la riqueza del arzobispo y cabildo compostelanos, que la disfrutaban, y por la agresividad de los cobradores. ${ }^{11}$ El pergamino fue vapuleado en un largo pleito entre la catedral compostelana y cinco obispados castellanos exentos, ya que el abogado Lázaro

\footnotetext{
${ }^{9}$ González López, E. 1967. «Cervantes y el patronato único del Apóstol Santiago», Grial 17: 365-69. Moner, M. 2005. «Le prix de la sainteté», en Ch. Couderc y B. Pellistrandi (eds.), Por discreto y por amigo: 121-130. Madrid: Casa de Velázquez.

${ }^{10}$ Péricard-Méa, D. 2011. Le Matamore. Mythe, images et réalités : 66.Cahors: La Louve éditions.

${ }^{11}$ Rey Castelao, O. 1985. «La renta del Voto de Santiago y las instituciones jacobeas», Compostellanum 3-4: 323 .
} 
González de Acevedo basó la defensa de estos en su falsedad y publicó al respecto un alegato de amplia repercusión; en consecuencia, la Chancillería de Valladolid sentenció contra del arzobispo y el cabildo compostelanos en 1592, lo que fue corroborado por el Consejo en 1628, en pleno debate del segundo patronato de Teresa. ${ }^{12}$

Se puede añadir que los cambios en las prácticas religiosas promovían a santos más cercanos a la vida, menos belicosos y más interioristas, con santuarios próximos, y que habían caído a mínimos las peregrinaciones -Felipe III anunció la suya en 1610 pero no la cumplió-, por las prevenciones eclesiásticas y civiles contra los movimientos de radio largo. ${ }^{13}$ Además, en una etapa de profunda devoción a las reliquias, las del Apóstol se habían ocultado en 1589 con pretexto de protegerlas de un ataque del corsario Drake a Compostela, pero en realidad ante el temor de que Felipe II quisiera llevarlas a El Escorial -lo ha estudiado L. Burgos Hervás- $-^{14}$ y a la inspección ocular permitida por el Consejo de Castilla en el mencionado pleito.

En los mismos años floreció la literatura sobre la Inmaculada Concepción de la Virgen y varios tratados publicados en 1616 y 1617 a su favor fueron obra de carmelitas; esta otra polémica religiosa oponía el fervor mariano hispano a la cautela de Roma, pero en 1622 el papa aprobó ese culto: esta renovación del culto a la Virgen, como en otras épocas, iba en detrimento del culto al Apóstol al disminuir su protagonismo; la relación entre la polémica concepcionista y la del patronato fue señalada por Godoy Alcántara en 1868 en la doble intervención de don Pedro de Castro. ${ }^{15}$ También iban contra el prestigio del Apóstol los escritos que por entonces se publicaron en torno al Pilar de Zaragoza -en 1616, el de Diego Murillo- ya que reivindicaban la intervención de la Virgen en la evangelización de Hispania ante la inoperancia de Santiago, lloroso a las orillas del Ebro.

\section{El SEGUNDO PATRONATO}

El segundo episodio es más complejo, ya que a esos factores señalados se unieron otros muy alambicados, y su repercusión fue mayor por ser más duradero e intervenir personajes como el conde-duque de Olivares y el escritor Francisco de Quevedo. En 1626 desde Zaragoza, Felipe IV escribió al

\footnotetext{
${ }^{12}$ Rey Castelao, O. 1993. El Voto de Santiago. Claves de un conflicto, Santiago: Xunta.

${ }^{13}$ López López, R.J. 1992. «El Camino de Santiago en la Edad Moderna». Compostellanum: 46. O. Rey Castelao. 2004. «Le Chemin de Saint-Jacques à l'Époque moderne. Une revisión». Revue d'Histoire de l'Eglise de France 224: 109-130.

${ }^{14}$ Burgos Hervás, L. 1996. «Felipe II y las reliquias del Apóstol Santiago», Iacobus: 83.

${ }^{15}$ Barrios Aguilera, M. 2011. La invención de los libros plúmbeos: 122-145. Granada: Universidad.
} 
presidente del Consejo de Castilla para que propusiese de nuevo a las Cortes el patronato de Teresa; pronto se promulgó el decreto y se gestionó la aprobación papal, cuyo breve de 21-VII-1627 -impreso con urgencia-, establecía que se hacía sin embargo del patronato de Santiago. Para celebrarlo, Felipe IV mandó hacer fiestas y ordenó reunir los sermones que no pudo oír en una Relación publicada en 1627, donde se indica que era iniciativa suya y no «acción de otra persona», quizá para neutralizar el rumor de que era Olivares el instigador del nuevo patronato. La Relación relata las arquitecturas, músicas, fuegos, y revela la diversidad y prestigio de los predicadores, lo que da a entender la amplia acogida del cambio y el interés de la monarquía. Los predicadores se quejaban de que apenas podían decir nada nuevo, pero en su reiteración construyen un discurso sobre la santa y su patronato en el que se defiende su condición femenina: su vida, obras, virtudes, ejemplaridad como maestra de la vida, profetisa divina, heredera de Isaías y de Elías, renovadora de su celo, valedora de España, nueva defensora de la fe y de la santidad, universal refugio, amparo de necesitados, etc., aunque para no menoscabar a Santiago, alababan las ventajas del doble patronato. ${ }^{16}$

Hubo muchos e importantes pronunciamientos a favor de santa Teresa que subrayaron la faceta piadosa del tema: su co-patronato aparece como el reconocimiento de un tipo de religión nuevo, intimista, apartado del anacrónico belicismo de Santiago, e implica un enriquecimiento de la Iglesia al incrementar el número e importancia de los mediadores entre el cristiano y Dios. A la cabeza estuvieron Morovelli de Puebla y Balboa de Mogrovejo, el obispo de Córdoba Cristóbal de Lobera, y fray Pedro de la Madre de Dios ${ }^{17}$ definidor carmelita y emparentado con Olivares, en lo que se han visto complejas influencias. Entre los argumentos destacan que Teresa era natural de España y que su cuerpo estaba aquí, y el afecto y devoción generales a una reformadora de hombres y mujeres, favorecida y regalada por Dios, abogada contra los males, introductora de la oración mental y del trato espiritual, de la devoción al Sacramento y a San José, e instigadora del aseo y el ornato en el culto, así como su condición de doctora de la Iglesia o la repercusión internacional de sus libros.

Si Teresa contaba con el rey y con su valido, el frente jacobeo no era débil. El cabildo compostelano escribió al papa pidiendo la suspensión del breve y a las

\footnotetext{
${ }^{16}$ Nos remitimos a los artículos de F. Cerdán y F. López Estrada que citaremos más adelante.

${ }^{17}$ Candelas Colodrón, M.A. 2006. «Los escritos de Balboa de Morgovejo y Fray Pedro de la Madre de Dios en «Su espada por Santiago» de Quevedo». Nueva revista de filología hispánica, 54-1: 191207. Del mismo autor: 2006. «Quevedo contra Balboa: «un contraste de diamante», Revista de Erudicion y Crítica 1: 83-90. 2007. «Los escritos del Arzobispo de Santiago, de Fray Pedro de la Madre de Dios y el papel titulado «Justa cosa ha sido elegir por patrona de España y admitir por tal a Santa Teresa» en el «Memorial por el patronato de Santiago» de Quevedo», Boletín de la Biblioteca de Menéndez Pelayo. 83: $111-128$
} 
iglesias castellanas para neutralizar el cambio $(24-\mathrm{X}-1627),{ }^{18}$ e inició una guerra que duró hasta 1630, en la que activó toda su influencia y recursos para defender la primacía de Santiago, dadas las consecuencias morales y económicas de la pérdida del patronato único. Pero sobre todo promovió una campaña de textos, obra del arzobispo González Villalobos, de miembros de cabildos con tradiciones vinculadas a Santiago -Astorga, Sevilla, Jaén-, instituciones santiaguistas -aunque la actitud de la Orden de Santiago no fue clara-, unos por encargo del cabildo -Quevedo, Astorga del Castillo-, y otros por un impulso personal, como Losada Quiroga o Salgado de Araújo. ${ }^{19}$ Al plantearse como un debate religioso-literario e histórico-político, los autores emplearon un tono polémico y apologético y fórmulas jurídicas y argumentos históricos, que fueron refutados en todos sus puntos por los teresistas.

Pero la polémica adquirió su punto álgido cuando intervino Quevedo, el autor que más se implicó en la causa jacobea, redactando en 1628 el Memorial por el patronato de Santiago y Su espada por Santiago, y un poema contra el patronato de Teresa; además, mantuvo un intenso epistolario con el cabildo de Santiago -su instigador- $-{ }^{20}$ con los partidarios de Teresa e incluso escribió al papa, al rey y a Olivares. Su devoción al Apóstol, su respeto a la tradición y su condición de caballero de la Orden de Santiago, pero también su intención de atacar a Olivares y la oportunidad de publicar sus ideas políticas, traspasan esa intensa intervención y explican la trascendencia que el tema adquirió en el futuro. Quevedo opinaba que la actitud de las Cortes al atender la petición de los carmelitas era contraria a la competencia del papa en materia de patronato -las Cortes contravenían un precepto divino-; que la petición venía de un sector restringido pero las Cortes la habían convertido en un acuerdo de aplicación general; y que la alteración en el patronato ponía en peligro la «conservación» de España, dependiente de la protección apostólica. Pero, yendo más allá, atacó a la figura de Teresa, recordando que sus libros habían sido sospechosos a la Inquisición, y que era una virgen atada a una rueca -no una escritora como la presentaban sus partidarios-, mientras Santiago había sido apóstol, evangelista y profeta, muy por encima de ella en la escala celestial.

\footnotetext{
${ }^{18}$ Santos Fernández, C. 2004. «Correspondencia entre los cabildos catedralicios de Astorga y Santiago en torno al copatronato de Santa Teresa (1627-1632)». Astorica 23: 105-144.

${ }^{19}$ Santos Fernández, C. 2004. «Impresos en defensa del Patronato de Santiago: el memorial de fray José González de Villalobos a Felipe IV». Pliegos de Bibliofilia 25: 17-31; 2003. «Génesis de un impreso salmantino del siglo XVII en defensa del Patronato de Santiago: la defensión apologética de Juan Salgado de Araújo». Compostellanum: 615-671. 2004. Impresos en torno al patronato de Santiago, siglo XVII. Santiago: Xunta

20 Díaz Fernández, J.M. 1995. «Francisco de Quevedo y el cabildo compostelano», en S. Fernández Mosquera (ed.), Estudios sobre Quevedo: 105-118. Santiago: Universidad. Fernández Mosquera, S. 2009. «Quevedo, Galicia y Santiago: una relación tópica y de conveniencia», en J. Alvarez Barrientos y otros (coords.), En buena compañia: 265-276. Madrid: CSIC.
} 
Quevedo fue apoyado por los cabildos de Santiago y de Toledo y por diferentes personajes de la Corte y de fuera de esta, y fue atacado por muchos otros, a nombre descubierto o bajo seudónimo. Algunos muy significativos le recriminaron con elegancia su injusta acritud con la santa: el prior de descalzos de Madrid, Francisco de la Concepción, y la sobrina de santa Teresa, Beatriz de Jesús, le hicieron notar que los carmelitas no habían solicitado el segundo patronato. Pero otros lo hicieron con saña, en especial Valerio de Vicencio, es decir, Gaspar de Santa María. Como consecuencia o no de esto, Quevedo se retiró a su pueblo, donde compuso Su espada y la respuesta a Balboa de Mogrovejo, que dirigió al rey con carta a Olivares a través de Álvaro de Villegas, aunque este no aceptó el encargo. Volveremos sobre esta cuestión.

A pesar de que el rey escribió en 1628 al embajador en Roma, conde de Oñate, mandando que se opusiera a todos los que cuestionaban la validez del breve de 1627, y que Olivares escribió, además, a los cardenales Pio y Torres,${ }^{21}$ la fuerza del bando jacobeo y quizá la abstención de los carmelitas -así se da a entender en las crónicas de la orden-, influyeron en la restauración del patronato único de Santiago en 1629. El breve papal de revocación se dio a conocer con urgencia desde Compostela enviando noticia a las ciudades en carta de 22-II-1630. En el mismo año, otro breve ordenó a los conventos carmelitas que reconociesen la nueva situación, y en Roma y en Santiago se imprimió el decreto papal que disponía las normas para elegir patronos (23-III-1630), cuya inexistencia había favorecido los dos episodios del compatronato. Además, y a pesar de las reticencias del papa, la Congregación romana para la reforma del breviario, borró el carácter de tradición particular que Clemente VIII había dado a la de Santiago, restituyéndola en su carácter universal e histórico, algo que A. Fernández-Guerra atribuyó en 1859 a la actitud favorable de varios italianos y de los representantes de Francia, y sobre todo, a la falta de interés en reemprender la discusión sobre esa tradición.

Pero la tranquilidad no era total en la catedral compostelana, de modo que en 1631 el cabildo denunció ciertas maniobras para que Teresa fuera patrona de los seglares que quisieran admitirla, y que en Roma se movían los hilos «solo con el fin de llevarse tras de sí al vulgo y adquirirse el lado de los reyes», insistiendo a su delegado en la Corte, el canónigo Fernández de Navarrete, para que actuase en consecuencia. ${ }^{22}$ Además, el cabildo pedía a las iglesias castellanas que denunciasen todos los carteles, inscripciones y referencias al patronato de Teresa, y así fue como en 1631 se prohibió una letanía titulada Hispaniarum patrona. ${ }^{23}$

\footnotetext{
${ }^{21}$ Rowe, E.K. 2006. «St. Teresa and Olivares: Patron Sainthood, Royal Favorites, and the Politics of Plurality in Seventeenth-Century Spain». Sixteenth Century Journal 37-3: 721-737.

${ }^{22}$ Iglesias Ortega, A. 2000. «Pedro Fernández de Navarrete, un riojano en la catedral de Santiago». Berceo 138: 113.

${ }^{23}$ Tellechea, I. 1958. «Una letanía de santa Terea prohibida por la Inquisición». Espiritualidad carmeliticiae 9: 458-466.
} 
En 1643, Felipe IV estableció la ofrenda anual al Apóstol y en 1646 las Cortes de Castilla hicieron otro tanto, lo que equivalía a reconocer su patronato, pero ya por entonces la Corona había pretendido proclamar patrono a San Miguel, cuyo carácter belicista era parecido al de Santiago, pero añadía su condición de patrón de los godos y de arcángel, superior en rango a un apóstol. Teresa ya había pasado a un segundo plano.

\section{LA EVOLUCIÓN DEL TEMA ENTRE 1630 Y 1812}

El patronato de Teresa se adormeció a partir del brusco final de 1629/30. De hecho, es llamativo que las crónicas carmelitas no den datos o den pocos: fray Jerónimo de San José en su historia del Carmelo (1637), dedicada a Felipe IV, indica que la santa siempre tuvo el apoyo de los reyes, pero se limitó a decir que en 1617 las Cortes hicieron voto de tenerla por patrona; ${ }^{24}$ en Reforma de los Descalzos de fray Francisco de Santa María (1644) da cuenta del asunto. El silencio posterior es más llamativo porque Carlos II en un codicilo de su testamento, después de mencionar a «Santiago, Patrón de España», singularizaba a Teresa «de quien me he mostrado con tan particulares demostraciones devoto», $\mathrm{y}$ «haviendo deseado toda mi vida tenga el Compatronato de mis Reynos de España... por la especial devoción que la tengo, encargo a mi sucesor, y a mis Reynos, lo dispongan, como tan importante para sus mejores beneficios, que debe esperar por la interposición de esta Santa». ${ }^{25}$ El testamento se publicó en 1700 , pero los carmelitas no hicieron nada y Felipe V no cumplió el encargo, antes bien, este rey -de quien hay un retrato como Santiago en La Paz, Bolivia-, utilizó a su favor el culto a la Virgen del Pilar y al Apóstol, y en 1720 se prohibieron varios textos de Juan de Ferreras y de otros autores que contradecían la tradición jacobea, atacada cada vez más por parte de la historiografía extranjera y de la española más crítica. ${ }^{26}$

En el siglo XVIII se publicaron obras sobre Santa Teresa y sobre su orden sin mencionar o tratar el patronato. La excepción es Año Teresiano, del lector de teología del Colegio de San Cirilo de Alcalá, fray Antonio de San Joaquín (1735). ${ }^{27}$ Se trata de una síntesis fundamentada en documentos que luego serán repetidos

\footnotetext{
${ }^{24}$ San José, F.J. 1637. Historia del Carmelo descalzo: 191 y 275.

${ }^{25}$ Copia del testamento cerrado... y del codicilo...del Señor rey D. Carlos II, s.i., Madrid. 1700: 244, 266 y 271.

${ }^{26}$ Mestre Sanchís, A. 2002. «Nueva Dinastía e Iglesia», en P. Fernández Albaladejo, Dinastía y memoria de nación en la España del siglo XVIII: 565. Madrid: Pons y Casa de Velázquez. Rey Castelao, O. 1985: 123.

${ }^{27}$ San Joaquín, F.A. 1735. Año Teresiano, Diario Histórico, tomo II. Madrid: imp. de Manuel Fernández.
} 
abusivamente por otros autores y el inicio de una espiral en torno al tema de la que nos ocuparemos luego. Fray Joaquín parte de la importancia que para los cristianos tiene contar con patronos para entrar en el Cielo y atribuye el fracaso del compatronato de 1617/18 a la oposición de varios prelados porque Teresa no estaba canonizada, lo que no discute, y se centra en el segundo episodio, que no atribuye a Felipe IV sino que este se había «apoyado en casi todos sus vasallos», y, tomada la iniciativa por los diputados de las Cortes, el rey admitió el nombramiento y lo notificó al papa y a todos sus reinos. Según el autor, el rey manifestó su alegría por haber recibido 125 cartas a favor del patronato, lo que fray Joaquín avala con «copia del testimonio» del secretario real a petición de los carmelitas, donde figuran todos los cabildos, prelados y ciudades que habían admitido el patronato, documento que luego presentarán a las Cortes de Cádiz al proponer a Teresa como patrona. Fray Joaquín hace un intento de localizar la fidelidad a la santa, como luego hará E. Rowe en su monografía sobre el tema, como veremos, pero lo más significativo es que explica que el patronato de Teresa «permanece ahora muy deteriorado» por no estar en práctica, «o ya por la alteración de algunos acérrimos devotos de nuestro Gloriosísimo Santiago, Patrón antiquísimo de todas las Españas», por oposición o porque los carmelitas «no quisieron hacer parte después de revocado el breve». Para el carmelita, Felipe IV se había retractado, viendo «conmovidos a varones mui graves que contradecían este culto», manteniendo la línea carmelita de no volver sobre el caso y de ignorar el testamento de Carlos II. Esto no obsta para que fray Joaquín se faje en responder al Memorial de Quevedo, por la repercusión de la edición de las obras completas de este en 1729; fray Joaquín manifiesta su admiración hacia el escritor y disculpa su fidelidad al Apóstol por «otros respetos de no pequeña monta... que guardan los cavalleros de Santiago». Pero decide polemizar con un muerto porque había menospreciado a Teresa y para esto se basa en la legitimidad de los patronatos múltiples certificada por el Concilio de Trento, en que hubo otros patronos de la monarquía -Isidoro, Hermenegildo- y en que ser mujer no era negativo, como prueba la importancia de la Virgen -imagen de la prudencia-. Finalmente, recuerda que Teresa protegió siempre a la Corona, que se le debía la reforma de los conventos, su espíritu de oración, la pureza de la fe, y su genio ilustre. En realidad, fray Joaquín expuso el programa de los posteriores debates hasta los más recientes, en los que apenas se le cita.

En el resto del XVIII el patronato no se trató, pero en 1812 se imprimió en Cádiz y en Madrid un relato anónimo del nuevo patronato de Teresa en las Cortes de Cádiz, muy útil por contener el memorial de solicitud presentado por los carmelitas en 1811 y documentos como las actas municipales de Cádiz de 1618 y 1627. Con malicia se afirma no haber localizado el breve de revocación del patronato de Teresa sugiriendo su falsedad, lo que cuadraba con las sombras de falsificación que cubrían el culto jacobeo, y haberse obtenido del papa «sin noticia del rey y menos de las Cortes», sin juicio contradictorio y sin contar 
«con los representantes de los Reynos y sin obtener venia del Rey», volviéndose atrás Felipe IV «por razones políticas fáciles de entender al que sepa la historia de aquel reynado». También se recuerda el testamento de Carlos II -identificándolo con el «deseo de la nación»- y que las viejas rencillas carecían de sentido ante las urgencias de la invasión francesa, por cuanto la defensa de la fe exigía más recursos «ante los impíos que nos oprimen». ${ }^{28}$

El impreso anterior nos pone en línea con el tercer episodio del copatronato de Teresa. Lo que sucedió en Cádiz difiere de 1618 y 1626 en que no hubo una guerra de panfletos, no en vano el país estaba implicado en batallas mucho más importantes. La proclamación de Teresa como Patrona de España por los diputados reunidos en Cádiz estuvo precedida de la publicación de una biografía de la santa-La mujer grande (1807)- que destaca a la mujer fuerte y heroica, cuyo autor, el carmelita Manuel de Santo Tomás, sería relator de la causa del patronato; pero sobre todo, estuvo precedida por el movimiento contra las tradiciones jacobeas que sirvió a los diputados de Cádiz para abolir el Voto. Lo sorprendente es que la petición a favor de Teresa aparece en el proyecto de constitución de José María Peinado de 1810 enviado desde Guatelama, que encomienda la felicidad de la nación a la Inmaculada Concepción y anima al gobierno a insistir ante el papa para hacer efectivos los deseos del codicilo de Carlos II sobre el patronato de Teresa que «nació y floreció en Castilla y fue dotada de ciencia divina y de mui particulares prerrogativas fue enviada por Dios...para reformadora, desearía que se la eligiese y nombrase también por patrona de la nueva constitución que ha de establecerse en las cortes para bien y felicidad de la monarquía». La propuesta fue planteada por el diputado guatemalteco Antonio Larrázabal en 3-IX-1811. ${ }^{29}$

Lo que pasó luego consta en las actas y en el anónimo de 1812, donde se narra que «hallábase esta insigne española en cierto modo desairada en su misma patria», reparando las Cortes, con «toda su piedad» $\mathrm{y}$ «su autoridad soberana», el agravio cometido. En realidad, la petición del «reyno de Guatemala» no había prosperado, pero al obligar la guerra el traslado de los diputados al convento carmelita de Cádiz, la oportunidad fue aprovechada por los frailes para elevar un memorial acatando la constitución y retomando el patronato. Una comisión presidida por Joaquín Lorenzo Villanueva, dio por bueno lo aportado por los carmelitas: la proclamación de Teresa en 1626 fue anterior a las normas papales de 1630 sobre patronatos y no se perjudicaba a Santiago, ya que el patronato múltiple aparece en las normas canónicas y en las Partidas de Alfonso X; había

\footnotetext{
${ }^{28}$ Patronato de Santa Teresa de Jesús a favor de las Españas acordado por las Cortes Generales y extraordinarias el 27 de junio de 1812: 26-31. Cádiz: Manuel Ximénez.

${ }^{29}$ Barbas Homem, A.P. 2010. Constitucional Documents of Portugal and Spain: 291 Berlin: De Gruyter. En la restauración absolutista, Peinado fue destituido y Larrazábal encarcelado.
} 
precedentes históricos de que España y otros países habían tenido otros patronos; para Dios no había diferencia entre santas y santos -había muchas patronas- y que si Cristo eligió a Santiago, recomendaba rezar a muchos otros. El 14 de mayo de 1812 la comisión dio su dictamen y se leyó en las Cortes el 23 de junio, pero no se aprobó por unanimidad como dice el anónimo, sino que se validaron los acuerdos de las Cortes del siglo xvII, sin votar. El hecho se festejó en muchos lugares, especialmente en Ávila, donde el canónigo M. Aguado, encargado de un sermón dedicado a los diputados y a la Constitución -«testimonio de la fe de nuestros padres»- llegó a decir que el haber nombrado patrona a «nuestra ciudadana Santa Teresa» era una señal del cielo. ${ }^{30}$ La defensa del patronato de Teresa estuvo a cargo de los liberales, y los conservadores defendieron a Santiago, como símbolo de guerra santa contra Napoleón y la herejía, pero la principal derrota del Apóstol fue la supresión del Voto de Santiago en octubre del mismo año.

La vuelta de Fernando VII implicó reponer a Santiago como patrón, aunque los teresistas intentaron neutralizarlo publicando un Breve resumen de la vida de Teresa (Palma de Mallorca, 1814), anónimo y en verso que la presenta como patrona de España, y una biografía impresa en Valencia, obra de fray Juan de San Luis. Pero en 1816 el nuncio expuso al secretario de Estado de Roma que el cardenal de Borbón, arzobispo de Toledo y primado de España, había ordenado en las diócesis de su jurisdicción que se reconociese a Teresa, lo que protestó el cabildo de Sevilla, y que las Cortes y los carmelitas habían desobedecido el breve de Urbano VIII revocando su patronato. La Congregación de Ritos de 25-VIII-1816 dio la razón al nuncio y amonestó al primado y al superior de los carmelitas, lo que el nuncio pasó al gobierno, este a la Cámara de Castilla y esta prohibió el patronato, como explican Lasa y Laboa en el único trabajo sobre este período. En 1820, con la vuelta de los liberales al poder, el tema revivió al jurar Fernando la constitución y reponer a Teresa como patrona, a propuesta de un diputado de Ávila, con aprobación de la Junta provisional, por puro trámite. El nuncio Giustiniani escribió a Roma, pero constando que los únicos problemas eran el silencio de 1629 a 1812 y el decreto papal de 1816, comunicó que no estaba en contra de la reposición, si se solicitaba al papa; el ministerio optó por no implicarse y Roma se molestó con el nuncio, enviando el tema a la comisión de asuntos de España, que amonestó a Giustiniani pero dio por bueno que el gobierno hiciera aquella petición. El gobierno liberal no admitió tener que presentar solicitud alguna, desairando al nuncio, quien respondió que el patronato anterior a 1630 carecía de validez jurídica y que el decreto de 2-XII-1629 revocaba a Teresa, sin que las Cortes de Cádiz hubieran podido contravenirlo, pero el tema era irrelevante para el gobierno y desde 1821 el tema cayó en el olvido. ${ }^{31}$

\footnotetext{
${ }^{30}$ Martínez Ruiz, E. 2010. La Iglesia de España contra Napoleón: 265. Madrid: Actas.

${ }^{31}$ Lasa Iraola, I. y Laboa Gallego, J.M. 1980. «Santa Teresa de Jesús patrona de España en las Cortes de Cádiz». Hispania Sacra 32: 265-285.
} 
Con el final del período absolutista, el Voto de Santiago fue abolido y las ofrendas anuales sufrieron diversos avatares, pero santa Teresa no fue mezclada en ninguno de esos problemas.

\section{LA ESPIRAL QUE NO CESA}

Después de 1834, lo que nos interesa es la evolución del tema, ya que se generó una espiral en la que cada publicación fue añadiendo elementos interpretativos hasta llegar a las complejas construcciones teóricas de los últimos años. Esa espiral se inició con Año cristiano y con el anónimo de 1812, pero avanzó, tras un largo vacío, gracias Aureliano Fernández-Guerra al publicar las obras completas de Quevedo en 1859, junto con importantes documentos de la polémica, incluidos los que subrayan la actitud conciliadora de los carmelitas. ${ }^{32} \mathrm{~A}$ partir de entonces, como decíamos al principio, las trayectorias de santa Teresa y del Apóstol se entrecruzan y el culto a ambos se relanzó en el contexto de reforzamiento del catolicismo en la segunda mitad del XIX. Esto a su vez revitalizó las publicaciones en torno a ellos.

En 1882, el centenario de la muerte de Teresa fue clave en la recuperación y quizá distorsión del significado de su vida y de su obra, como señaló Giuliana Di Febo, ${ }^{33}$ pero el patronato no se trató o al menos, no en textos que hayan trascendido. En 1886, Teresa fue proclamada patrona de la Provincia Eclesiástica de Valladolid-compuesta en parte por diócesis desgajadas de la de Santiago-, aunque en los centenarios inmediatos no se incidió en el tema del patronato. En 1878, los restos del Apóstol, ocultos desde 1589, reaparecieron milagrosamente, en plena campaña de fomento de nuevos santuarios de peregrinación como El Pilar de Zaragoza, tan vinculado al culto jacobeo; certificada la autenticidad por León XIII, se procedió a exaltar el culto apostólico, la ofrenda y las peregrinaciones, como anunciaban en 1885 Fernández Sánchez y Freire Barreiro en su libro Santiago, Jerusalén y Roma, trío sacro tan desproporcionado como propagandístico. Para completar el éxito, el canónigo y archivero López Ferreiro publicó una gigantesca historia de la catedral de Santiago, obra de erudición de apariencia crítica, que en 1902 aportó documentos clave para estudiar el patronato de Santiago. ${ }^{34}$

En 1909 la ofrenda nacional fue presentada por Alfonso XIII, por lo que la consolidación del Apóstol como patrón era un hecho, ${ }^{35}$ pero el centenario de las

\footnotetext{
${ }^{32}$ Fernández-Guerra, A. 1859. Obras de Don Francisco de Quevedo y Villegas: 450. Madrid: B.A.E.

${ }^{33}$ Di Febo, G. 1989. «Per uno Studio sul terzo centenario della morte di Teresa de jesús». Teresianum 40: 491-515.

${ }^{34}$ López Ferreiro, A. 1902. Historia de la S.A.y M.Iglesia de Santiago. Santiago: Seminario.

${ }^{35}$ Palomares, J.M. 1981. «La política española y su reflejo en las Ofrendas al Apóstol Santiago», Cuadernos de Estudios Gallegos 32: 267-264.
} 
Cortes de Cádiz sirvió para recordar que Teresa había sido su patrona: en 1915 lo hizo un artículo de Silverio de Santa Teresa ${ }^{36}$ y en ese año la santa fue proclamada patrona de Intendencia Militar. ${ }^{37}$ Paralelamente se fue configurando la idea de la «santa de la raza» en publicaciones sobre la genealogía de Teresa, ${ }^{38}$ lo que se reforzó en torno al centenario de la canonización en 1922, vinculándola con los conceptos de hispanidad y de unificación creados en el cuarto centenario del Descubrimiento de América de 1892. La codificación de esa nueva función fue obra de Gabriel de Jesús -en La santa de la raza, 1919-1931- y de Silverio de Santa Teresa, como puso de relieve Giuliana Di Febo. ${ }^{39}$

Para compensar, la erudición jacobea hizo un notable esfuerzo, en especial el franciscano Atanasio López, cuya Bibliografía del Aspóstol Santiago (19191931), es clave en el tema del patronato, ya que publicó nuevos textos de la Biblioteca Nacional, la Real Academia de la Historia y de otros fondos, sin entrar en polémicas, ${ }^{40}$ y en 1924, otro erudito gallego, J. Filgueira Valverde, añadió más e hizo una lectura modernizada de López Ferreiro. ${ }^{41}$ Esa lucha encubierta entre eruditos decantados hacia Teresa o Santiago adquiría en torno a este un cierto matiz galleguista.

En la Segunda República se suprimió la ofrenda al Apóstol, pero la politización se agudizó en la Guerra Civil hasta una feroz manipulación. En 1934/35, Silverio de Santa Teresa recopiló los procesos de beatificación y canonización de la santa, en 1935-39 publicó Historia del Carmen, en cuyo volumen VII da noticias sobre el patronato, y en 1939 Santa Teresa de Jesús: símbolo supremo de la raza. Debe tenerse en cuenta que el año santo de 1937 fue aprovechado por Franco para restaurar la ofrenda y reconocer a Santiago como "patrón de España», no en vano la Guerra Civil era también una guerra de religión -así lo han planteado D. Péricard o B. Bennassar- ${ }^{42}$ pero al mismo tiempo, Teresa fue aupada en la simbología y liturgia franquistas -tema estudiado por Di Febo- ${ }^{43}$ hasta que en 1937 fue designada patrona de la Sección Femenina, como veremos.

\footnotetext{
${ }^{36}$ Santa Teresa, S. 1915. «El patronato de Santa Teresa en las Cortes de Castilla de 1617». Monte Carmelo 16: 300-304.

${ }^{37}$ Muñoz Sánchez, J.M. 1968. Santa Teresa, síntesis de su vida. Sus patronazgos. Avila: s.i.

${ }^{38}$ Gómez Centurión, J. 1916. Relaciones biográficas inéditas de Santa Teresa de Jesús ... dados á conocer con motivo del centenario de su natalicio, Madrid: Real Academia de la Historia.

${ }^{39}$ Di Febo, G. La Santa de la Raza. Un culto barroco en la España franquista: 78-80. Barcelona: Icaria.(1 $\left.{ }^{\mathrm{a}}, 1987\right)$.

${ }^{40}$ López, F.A. 1947. Nuevos Estudios histórico-críticos acerca de Galicia, 1, Madrid. CSIC.

${ }^{41}$ Filgueira Valverde, J. 1924: «Nuevos documentos para la historia del patronato jacobeo», Boletín de la Real Academia Gallega XIX: 89.

42 Bennassar, B. 1970. Saint-Jacques-de-Compostelle. París: Juliard. Péricard-Méa, D. 2000. Compostelle et cultes de Saint Jacques au Moyen Age. París: PUF.

${ }^{43}$ Di Febo, G. 1988. 2012. Ritos de guerra y de victoria en la España franquista. Valencia: Universidad.
} 
LOS EPISODIOS BARROCOS DEL PATRONATO EN LA HISTORIOGRAFÍA, DE LA POSGUERRA A LA ACTUALIDAD

En el período de posguerra y hasta los años ochenta del siglo xx, el tema del patronato apenas se tocó de un modo crítico. Fuera de la bibliografía apologética de uno u otro lado, reapareció en relación con los escritos de Quevedo. En 1945 Jacqueline Boyer presentó en París una memoria de diplomatura sobre el patronato, subrayando que los argumentos jurídicos y teológicos perdieron importancia ante el ataque de Quevedo, llegando a la conclusión de que al ganar este, España se había apartado de Europa. ${ }^{44}$ En el mismo año, J.A. Maravall, llamó la atención sobre el tema al ocuparse de Mártir Rizo y del afecto de este hacia Quevedo, que lo llevó a meterse en una «violenta batalla religioso-literaria y a la vez histórico-política» de graves consecuencias para él, y en 1946 publicó un pequeño estudio sobre el tema de las Cortes en Quevedo,${ }^{45}$ poniendo de relieve la rareza de encontrar reflexiones sobre las Cortes en la bibliografía política moralista o en escritores prácticos del XVII. Para Maravall, Quevedo, poco entusiasta de juntas con matiz popular, hizo «unas escasas alusiones» en sus memoriales, y aunque usó argumentos de derecho romano, las Partidas y leyes antiguas, «sería excesivo dar una importancia a sus palabras mayor que la que tienen», sin embargo, le reconoce tres conceptos de interés: a) llama a las Cortes el Reino, pero al no estar representados ni nobles ni clero, equivalía a las ciudades; b) los individuos de las Cortes no son autoridad, sino particulares con poderes específicos; c) ni el reino ni solo el rey, ni este con el reino lo pueden todo, ya que la materia del patronato era ajeno a sus competencias, y habían concedido lo que no podían dar. Maravall concluye que «frente a una tesis desafortunadamente casticista... nuestro autor defiende la revocabilidad y la conveniencia de reforma de los actos del poder» y para eso se valía de la conciencia moral y religiosa. Maravall no tiene en cuenta que esos argumentos eran de autores pro-jacobeos anteriores a Quevedo, pero sitúa la cuestión del patronato en un plano político del que ya no se iba a apear.

El tema reaparece en Américo Castro, no en Teresa la Santa, sino en La realidad histórica de España, publicada en México en 1954, después de dejar la cátedra de lengua y literatura española de Princeton: la dedicación filológica y la vinculación con universidades norteamericanas son dos condiciones que comparten varios de los analistas posteriores. Castro se basó en parte de la bibliografía y en algunos sermones del XVII, cometiendo inexactitudes como que el papa había otorgado el patronato en 1618. Pero supo situar el debate en el

\footnotetext{
${ }^{44}$ Boyer, J. L 'Aspect littéraire de la querelle au sujet du patronal de l'Espagne: saint Jacques ou sainte Thérése, comentado por F. López Estrada (1984 : 646-47).

${ }^{45}$ Maravall, J.A. 2001. Estudios de historia del pensamiento español: 293-361 Madrid: Ed. de Cultura Hispánica.
}

Hispania Sacra, LXVII

136, julio-diciembre 2015, 531-573 ISSN: 0018-215X, doi: 10.3989/hs.2015.016 
declive del mito de Santiago y en la desafección de los reyes, en la reconversión de la figura del héroe arrastrada desde el siglo XvI, en la exaltación de la «casta triunfante», y en que el centro político estaba ya solo en Madrid, muy alejado de Compostela, la periferia. Castro considera que la polémica alborotó al país como si afectase a la existencia de la nación: no había territorios a reconquistar y los Felipes llevaban un gobierno administrativo-político, de modo que el debate, parecido a un pleito judicial, fue «una discusión entre leguleyos y agentes de negocios». Ante algunas sugerencias de que los partidarios de Teresa representaban la modernidad, Castro niega que fueran «descreídos racionalistas», aunque reconoce cierto racionalismo en la crítica a la eficacia celestial de Santiago: pero ahí radicaba el riesgo de un cambio, ya que si se prefería el propio juicio a la creencia tradicional, hubieran podido desmoronarse otras creencias. Los adversarios de Santiago «usaron su escepticismo para intentar aniquilarlo pero no para edificar ninguna verdad fundada en pensamiento», limitándose a matar una creencia y a poner otra igual de medieval, en una aparente dualidad muy del siglo XVII -Castro busca paralelismos en la literatura y en los arbitristas-; además, se renegó de Santiago «por boca, no de la plebe ignorante sino de sus frailes y teólogos», y comparando los conventos con salones, estos «favorecían a la santa y las masas al apóstol». En cuanto a Quevedo, caballero de Santiago, se vio reducido a villano al descabalgar el patronato, llamando a los carmelitas débiles y «afeminados», y escribiendo «cosas incré́bles» y «ultramedievales». En fin, el patronato enfrentó una concepción pragmática y activista de lo divino con la vivencia de Dios en la contemplación, «la ociosidad mendicante» de unos conventos que habían creado una España dentro de otra, y donde la lucha entre las órdenes por su prestigio había derivado en un «cantonalismo del espíritu». ${ }^{46}$ El debate carecería de relación con el contexto europeo porque el Barroco y la Contrarreforma eran vividos desde dentro: un Felipe IV que prefería las letras a las armas reculó finalmente porque «la mayoría de los españoles se rebeló». Castro, a pesar de denunciar la «riqueza mundana del cabildo compostelano», erró al considerar que el Apóstol tenía el respaldo popular.

En 1960, el inglés T.D. Kendrick (1895-1979), arqueólogo e historiador del arte, publicó Saint James in Spain ${ }^{47}$ hábil síntesis que utiliza ideas de Godoy Alcántara, Atanasio López y Fernández-Guerra. Pero tiene la virtud de relacionar el nombramiento de Teresa con la crisis de las tradiciones jacobeas, y con el reforzamiento del Pilar de Zaragoza. Kendrick indica las ventajas que podía aportar Teresa a Felipe IV: era moderna, popular y admirada en su personalidad, comprendía los problemas sociales y políticos de su época, había sido brillante en la administración y el negocio, sus imágenes estaban por todas partes, sus libros

${ }^{46}$ Castro, A. 1962 . La realidad histórica de España: 390-396-399. México: Porrúa. Castro, A. 1958. Santiago de España. Buenos Aires: Emecé Ediciones.

${ }^{47}$ Kendrick, T.D. 1960. Saint James in Spain: 61, 62 69. Londres: Methuen. 
eran famosos, etc., pero que aún siendo los argumentos a favor de Santiago bien contrarios a esos, no se pudo correr el riesgo de enfadarlo, un juicio un tanto banal que no evita la frecuente cita de esta obra en la bibliografía anglosajona.

Dado que los pronunciamientos sobre el tema se basaban siempre en los mismos datos, fue importante que en 1972, Isaías Rodríguez publicase una guía de las fuentes de posible uso, utilizando el material de la Biblioteca Nacional, en especial el legajo 9140 que contiene los documentos esenciales de la polémica del patronato. De esta guía se ha hecho un uso frecuente, sin citarla, como sucede con muchas obras instrumentales. Isaías Rodríguez hacía además una recomendación: la necesidad de ordenar cronológicamente los argumentos para no alterar la interpretación de los hechos, algo que por obvio que pueda parecer, no se estaba haciendo. ${ }^{48}$

Esa operación es esencial para analizar los procesos del patronato y saber quién dijo qué -esto resituaría la intervención de Quevedo, por ejemplo-, pero también el tratamiento bibliográfico del tema para ver quién se ha aprovechado de quién y cómo los episodios del patronato se han agigantado a medida que cada nuevo estudio reduce cada vez más la observación, perdiendo el horizonte de los problemas importantes de los momentos en que se produjeron, o llevando el tema a territorios ajenos. En parte esto se debe a que muchos de los autores son filólogos que han valorado más los textos y sus autores -Quevedo en especial- que el verdadero impacto de los cambios de patronato. Frente a la importancia que unos le han concedido, llama la atención que una parte cualificada de la bibliografía siga considerándolo como un tema significativo pero episódico, menor dentro de los que ocupaban a la monarquía o a la Iglesia.

Haciendo el seguimiento de atrás adelante, debe subrayarse que los congresos del centenario de la muerte de Teresa apenas trataron el patronato. En el referido a santa Teresa y la literatura mística hispánica, hay solo un artículo de Francis Cerdán - especialista en la oratoria sagrada del XVII- sobre la Relación de 1627, de la que presenta los rasgos de Teresa que subrayan los sermones y la reiteración de los temas, a pesar de la diversidad de los predicadores, sin profundizar en si hubo o no un debate entre modernos y antiguos, pero señalando algunos ecos al respecto. ${ }^{49}$ En el congreso de Salamanca de 1982, entre cincuenta aportaciones, solo la del filólogo Francisco López Estrada trata el tema en un estudio sobre la misma Relación; este autor reconoce basarse en I. Rodríguez, pero él mismo había estudiado las fiestas teresianas en ciudades andaluzas, como especialista que era en el género de las relaciones. Estrada propone una lectura compleja de lo que califica como un «episodio de la vida

\footnotetext{
${ }^{48}$ Rodríguez, I. 1972: 109-129-137.

${ }^{49}$ Cerdán, F. 1984. «Santa Teresa en los sermones del Patronato (1627)», Santa Teresa y la literatura mística hispánica: 610. Madrid: EDI6.

Hispania Sacra, LXVII

136, julio-diciembre 2015, 531-573 ISSN: 0018-215X, doi: 10.3989/hs.2015.016
} 
cultural de la época de Felipe IV» con implicaciones religiosas o políticas, y de lo que pudo representar el intento de ensalzar a Teresa «como representación de la monarquía española y su desvanecimiento casi repentino en medio de una conmoción política». ${ }^{50}$ Por orden real -y no de Olivares- se había dado a las fiestas del patronato una dimensión popular por cuanto el pueblo de Madrid y la Corte participaron en su celebración, revelando un acuerdo entre el rey y muchos súbditos en elevar a una mujer y nueva santa. La Relación sería la culminación del esfuerzo a favor de la santa y por eso se reclutó a predicadores de primera fila. La reiteración de temas escondía un sustrato común y el recurso a citas latinas obedecería al prurito culto, pero también al gusto del público por las «oleadas retóricas». El patronato reconocía la capacidad milagrosa de Teresa para proteger y defender a la monarquía de un modo nuevo, basado en la reforma y la renovación, pero con retazos tradicionales -heridas, visiones-; la armonía en las parejas ilustres, de las armas y las letras, la guerra y la paz, reforzarían la protección. La condición femenina de Teresa es la que exigió más esfuerzo por lo que se señala su actividad, su novedad, gobierno y autoridad y su condición de escritora y sobre todo su españolidad, ya que por naturaleza y andanzas abogaría por los españoles frente al terror del africano, frenaría al inglés y sería cuchillo de herejes. Para Estrada, todos los sermones se acomodaban a lo que querían oír los nobles de la Corte y la hidalguía, de modo que en el debate se sobrepasó el tono religioso derivando en una violenta cuestión de principios sobre la sociedad, entre dos concepciones dentro del mismo cuerpo político: Santiago representaba el pasado secular y los privilegios de linaje, riquezas y rentas; Teresa, la humildad que solo obtiene reconocimiento de sus virtudes en la lucha por la santidad, abandonando la riqueza y dignificándose a través de la pobreza espiritual. El grupo teresista era heteróclito -reyes, validos, frailes, algún obispo, concejos, ciudades- y parecía esperar algo de modernidad, pero el rey, el papa y Olivares no lograron sus objetivos «porque existían acciones políticas de fuerza suficiente como para ganar la partida al mismo rey». En fin, la polémica discurrió en las coordenadas del absolutismo y en una estrecha relación entre Iglesia y política: la Relación hizo público un complejo entramado de opiniones e intrigas que pasó de grupos reducidos a comunicar con la nación en definitiva, representó el planteamiento de una incógnita cultural.

En 1984, dedicamos al patronato un capítulo amplio de nuestra tesis doctoral, publicado en un libro sobre la historiografía barroca del culto jacobeo. ${ }^{51}$

\footnotetext{
${ }^{50}$ López Estrada, F. 1984. «Cohetes para Teresa: la relación de 1627 sobre las fiestas de Madrid por el Patronato de España de Santa Teresa de Jesús y la polémica sobre el mismo», en T. Egido (ed.), Congreso internacional Teresiano: 654-670. Salamanca: Universidad. 1982. Fiestas por Santa Teresa de Jesús en Málaga y en Antequera (1618 y 1627). Antequera: Caja de Ahorros.

${ }^{51}$ Rey Castelao, O. 1985. La historiografía del Voto de Santiago. Recopilación crítica de una polémica histórica. Santiago: Universidad.
} 
A lo largo de esas páginas entreveramos nuestras ideas sobre qué significó la polémica del patronato en la evolución de ese culto y en la oposición al Voto de Santiago, comparando los cambios en el patronato a favor de Teresa con otros que hicieron peligrar el del Apóstol, y subrayando que no puede hacerse una interpretación aislada de esos elementos, en especial del económico. Defendíamos además que la entronización de Teresa no supuso su triunfo, ya que después de los cambios de actitud de Felipe III y Felipe IV, venció el sector jacobeo, como era de esperar en un ambiente conservador y celoso de «las glorias de España» cuando el imperio daba evidentes signos de decadencia. La documentación custodiada en la catedral de Santiago fue esencial para proponer una perspectiva apegada al archivo, de la que es difícil extraer las derivaciones en clave política que vinieron después, ya que todo apuntaba hacia intereses sociales y materiales de baja altura moral.

Así pues, en los años ochenta el tema del patronato cambió de lugar y de dimensiones por dos razones. En primer lugar, algunas llamadas de atención por parte de historiadores políticos como John Elliott, quien en su obra sobre Olivares (1986) afirmaba, en unas cuantas líneas, que la violenta polémica sobre el patronato, lo había sido sobre la identidad española y que al proclamar a Teresa patrona en 1626 desde Zaragoza, en el contexto de la Unión de Armas, había sido una provocación; ${ }^{52} \sin$ ir más allá, la difusión de su obra abrió la puerta a otros autores para seguir esa vía. Es el caso de Antonio Feros (2004), autor de formación americana, que consideraba que Felipe III buscaba un patrón menos belicista como símbolo de su política pacificadora y que la debilidad de la monarquía explica en parte la necesidad de reforzar el patronato: Teresa servía para construir un nuevo mito, en una fase de repliegue ideológico y mental, y de cierre de la monarquía. Además, Felipe III pretendía una plataforma de soberanía más elevada, la razón de Estado, un supremo interés monárquico cuya defensa era crucial para el rey, pero incluso los defensores de la razón de Estado, influyentes en la Corte, creían que la fe era esencial para mantener el poder real y la unidad religiosa de los territorios. ${ }^{53}$

Poco después de la obra de Elliott y sin referencia en este autor, se publicó el libro de Giuliana Di Febo que añade un elemento nuevo, el inicio de la construcción de la imagen de Teresa como santa de la raza, presente en los procesos de beatificación y canonización y en las piezas literarias que exaltaron a la mujer fortis y con linaje, caracteres que se agravarían en el debate sobre el patronato. En este se opusieron dos modelos de santidad, la nueva y útil, y la

${ }^{52}$ Elliott, J.H. 1986. The Count-Duke of Olivares. Yale U.P. (327-328 de la edición de Barcelona, 1990).

${ }^{53}$ Feros, A. 2004. «Por Dios, por la patria y el rey: el mundo político en tiempos de Cervantes», A. Feros y J.E. Gelabert, dirs., España en tiempos del Quijote: 61. Madrid: Taurus.

Hispania Sacra, LXVII

136, julio-diciembre 2015, 531-573 ISSN: 0018-215X, doi: 10.3989/hs.2015.016 
ligada a la reconquista, la ejemplaridad monacal y mística, el ejercicio de las virtudes y la actividad escritora y reformadora de la santa, frente al martirio/ vindex hostium de Santiago, la popularidad de Compostela o el prestigio de la Orden de Santiago; la espada y la pluma o la hispanidad bélica del Matamoros y la hispanidad triunfante de Teresa, capaz de proteger a la monarquía, perfilando así el tópico del símbolo del catolicismo hispano en una figura con atributos masculinos y femeninos..$^{54}$

En segundo lugar, es preciso señalar la enorme influencia de los numerosos estudios sobre los memoriales de Quevedo. En 1967, Doris L. Braum en su obra sobre el tradicionalismo del escritor, situó la intervención de Quevedo a favor de Santiago como la defensa de una tradición religiosa y de preservación de la nación, y como el deber personal de un caballero de Santiago para con los otros caballeros y con la Orden de Santiago ${ }^{55}$ Pero fue desde los años ochenta cuando se prestó más atención al tema. En 1984, Juventino Caminero, en un análisis semiótico sobre el pensamiento político-social del escritor, tomando como referencia a Maravall para calificar a Quevedo como absolutista cristiano, planteó el debate en sus mismos términos ${ }^{56}$ Por su parte, Carlos M. Gutiérrez, en 1992, en un amplio «estudio hermenéutico socio-cultural» sobre el escritor, propone que en el asunto del patronato, Quevedo sería el representante de la pequeña nobleza con una concepción monárquica acompañada del derecho divino, un autor ansioso que en la polémica jugó un papel «claramente desproporcionado», centrando sobre sí la tesis favorable a Santiago, lo que le acarrearía el destierro. ${ }^{57}$ Terminamos este breve repaso con Francisco Vivar, quien en 2002, partiendo de Castro, Kendrick y Elliott sostiene que bajo Felipe II España se había cerrado sobre sí, pero que existiendo territorios diversos -Cataluña, Galicia, País Vasco (sic)-, se hacía necesario unirlos a través de la religión, que era también el impulso del imperio, y que la controversia del patronato es un indicador de problemas más amplios: una sociedad en crisis que necesita revitalizar sus mitos nacionales; así pues, si Quevedo en España defendida afirma que los españoles son el instrumento de Dios, y sitúa al rey por encima del papa, en la defensa de Santiago, subraya la unidad social que ofrece un patrono único basado en pruebas y evidencias- y el peligro de la novedad de Teresa por cuanto resquebrajaba la tradición. Vivar introduce un elemento nuevo: la unidad cultural. Quevedo, cuya vehemencia en la defensa de Santiago es la voz militante

${ }^{54}$ Di Febo: 1988: 78-80.

55 Braum, D.L. 1970. Traditionalism in the works of Francisco de Quevedo y Villegas. Chapell Hill: Un. North Carolina.

${ }^{56}$ Caminero, J. 1984. Víctima y Verdugo: conservadurismo y antisemitismo en Quevedo (Problemata semiótica): 15. Kassel: Reichenberger ed.

${ }^{57}$ Gutiérrez, C.M. 1992. La espada, el rayo... Quevedo y los campos literario y de poder: 219-236. Indiana: Purdue U.P. 
de la España tradicional, sostiene que una nación representada por dos sería una nación dividida, que el poder político estaba obligado a defender los valores tradicionales que Santiago simbolizaba y que ni el rey ni las Cortes podían cambiar un patronato otorgado por Cristo. ${ }^{58}$ No nos detendremos en todos los estudios que se dedicaron luego a la retórica de los memoriales de Quevedo, publicados algunos en Estados Unidos, lo que confirma el interés ultramarino por el tema, quizá porque parte de los textos del patronato se conservan en instituciones americanas.

Las dos vías que acabamos de indicar tuvieron el efecto de ir añadiendo elementos de interpretación al debate del patronato, de modo que cada autor propone su propia relectura y el siguiente la acepta o la modifica, sin añadir documentación, en el caso de los historiadores porque abordaron el tema de forma tangencial en obras sobre los reinados de Felipe III y Felipe IV, y en el de los filólogos e historiadores de la literatura porque se centraron en Quevedo, y la figura del escritor se sobrepuso a Santa Teresa. De ahí nuestro interés en la sucesión cronológica de la bibliografía.

Nuestra sensación de que el tema se había ido convirtiendo en algo bastante ajeno al problema de origen, fue compartida por Márquez Villanueva, filólogo vinculado con López Estrada y catedrático en universidades americanas, en cuyo ensayo sobre el mito del Apóstol, publicado en 2004 y hecho solo a partir de bibliografía, se expresa con cierta dureza al respecto. Márquez contextualiza el problema en la decadencia del culto jacobeo y considera el patronato de Teresa dentro de los «mitos de relevo», lo que excluye que sea un caso único, atribuyendo el cambio al descontento y a una preocupación colectiva, en una sociedad descabezada con una veta de arbitrismo religioso y una «orfandad semi-neurótica de tantos españoles para acogerse bajo un nuevo palio sobrenatural», un medio eficaz de cobijarse en Dios mediante un nuevo hacedor, no en vano la tradición popular permitía la humillación pública y simbólica del patrono fracasado, Santiago. Márquez opina, como A. Castro, que la propuesta de Teresa coincide con el reformismo inicial de Olivares optando por un cambio radical -era mujer, sus reliquias eran auténticas-, pero rechaza las lecturas en clave de género y de oposición entre vida activa y contemplativa, caballería medieval y axiología mesocrática, y, aludiendo de modo sutil a autores ya citados, niega que en 1618 se hubiera entronizado a una «semi-burguesa» cuya espiritualidad formula un lenguaje de humildad, sino solo a una santa, un icono creado para el consumo oficial, eliminando la herencia anacrónica e inoperante del pasado medieval. Subraya el ímpetu juvenil de la idea y la renovación de las estructuras mentales que comportaba, y que los fenómenos hagiológicos acompañaban con naturalidad a los cambios sociales, pero también que Teresa no había calado en

\footnotetext{
${ }^{58}$ Vivar, F. 2002. Quevedo y su España imaginada: 100-108. Madrid: Visor libros.
} 
sectores populares, sino en grupos selectos, negando cualquier interpretación en línea popular. En alusiones veladas a los quevedistas, afirma que la fuerza de la oposición a Teresa, incluso frente al rey y al papa, «no ofrece ninguna dificultad hermenéutica porque con Santiago, asimilado a un arcaico sentimiento de identidad política y religiosa, no cabían paliativos ni transacciones». A diferencia de A. Castro, rebaja la oposición a una lucha entre grupos de activistas porque la sensibilidad religiosa no estaba socialmente estratificada y funcionaba en oleadas colectivas como la referida a la Inmaculada; bien al contrario, las masas abandonaron a Santiago, hartas de pagar el Voto. Finalmente, Márquez también se centró en Quevedo, de quien subraya su condición de caballero de Santiago -aunque la Orden no se había movilizado a favor del Apóstol- y su servicio al cabildo compostelano -quizá por dinero y para avanzar en su carrera-, sin embargo de lo cual Quevedo consideraba estar haciendo alta política negando al rey y a las cortes su capacidad para entrar en materia de patronato. Pero en realidad, el tono general de la polémica era bajo, más guerrillero que teológico, y Quevedo no lo elevó porque tenía pocos materiales y desconocía la historia eclesiástica, de modo que en sus memoriales no hay sutileza ni más arte que la manipulación y los artificios retóricos, ya que compartía la «infantilización religiosa de la época»..$^{59}$

Así pues, tenemos el tema del patronato situado en un lugar más realista, que compartimos, sobre todo en la necesidad de no perder la perspectiva de que los episodios de entronización de Teresa fueron más bien operaciones fracasadas de limitar el peso de la tradición jacobea, y que la desafección de la monarquía bajo Felipe III y Felipe IV, constituía una paradoja porque los delegados reales seguían luchando en Roma por la restauración de esas tradiciones en la liturgia pos-tridentina. A esa línea dedicamos varios artículos y parte de un libro sobre los mitos del Apóstol (2006). ${ }^{60}$ Sin negar la importancia política del tema, hemos procurado reubicarlo en el espacio eclesiástico-religioso, indagando en los verdaderos intereses sociales -incluso económicos- de instituciones y personas en apuntarse a uno u otro bando, y en los cambios de posición que protagonizaron muchos, lo que va en contra de las interpretaciones hechas solo en clave política.

La lectura política sugerida por Américo Castro y desarrollada sobre todo en medios académicos norteamericanos, ha dado en los últimos años varias muestras interesantes que se ignoran o se desconocen entre sí y que apenas tienen en cuenta

${ }^{59}$ Márquez Villanueva, F. 2004. Santiago, la trayectoria de un mito: 334-346. Barcelona: Eds. Bellaterra.

${ }^{60}$ Rey Castelao, O. 1988. «La monarquía y la Iglesia de Santiago», en J. M ${ }^{\text {a }}$ Díaz (ed.). Los Reyes y Santiago. Santiago: Xunta, pp. 43-58; 1999. «A Coroa e a igrexa de Santiago», Santiago e a Esperanza: 117. Santiago: Xunta. 2008. Los mitos del Apóstol Santiago. Vigo: Nigratrea. 
la bibliografía española que ha abordado el tema del patronato o sus afines. Pero sin duda, lo más llamativo es que el debate sobre el patronato tomase un rumbo cada vez más claro hacia el análisis del papel de las Cortes bajo los Felipes.

Esta línea se reforzó con Ch. Aguilar-Adan (2003-5), ${ }^{61}$ también relacionada con la historia de la literatura, que, haciéndose eco de la historia de la cultura política, incide en que causas como la del patronato, aparentemente lejanas del dominio político, provocaron divisiones duraderas y polémicas apasionadas en la Corte y fuera de esta. El episodio del patronato permite observar la transformación de una polémica religiosa y marginal en un conflicto religioso de orden mayor. La clave estaría en que una decisión que basaba su legitimidad solo por la autoridad de quien la tomaba, fue contestada por una parte de la Iglesia y derivó en un enfrentamiento con las Cortes, en el que la estrategia para desmantelar el patronato de Teresa se basó en deslegitimar la actuación de aquellas; el debate se inscribió en la cuestión de la autoridad de la Iglesia y del rey que transita los años veinte y treinta del xVII, de la representación del cuerpo social y del «reino» de España. La autora considera que fue un caso excepcional de intervenciones y tomas de posición corporativas -ciudades, Iglesia, Cortes-, al quedar cuerpos enteros de la república al margen de una decisión capital en lo simbólico y religioso. Rara vez se planteó el tema de la representación y la consulta de cuerpos y comunidades a través de concepciones antagónicas: la Congregación del clero elevó al rey una memoria pidiendo una junta de prelados y teólogos, pero las Cortes recurrieron a sus juristas y solicitaron la mediación real, y de por medio, un reguero de textos que llegaron a la difamación y el libelo, emplearon una gama de registros discursivos. Sin embargo, la fractura no fue limpia, sino que hubo militancias cruzadas -ni todos los juristas defendieron a las Cortes ni todos los canonistas a la Iglesia- e interpretaciones contradictorias de la actuación del poder temporal y espiritual, y las autoridades civiles y religiosas no actuaron como bloques solidarios. Los projacobeos, partiendo del cuerpo doctrinal común y de la definición civil y canónica del patronato, se centraron en qué autoridad estaba legitimada para decretarla según se considerase particular del público o común, excluyendo que las Cortes pudieran hacerlo por carecer de capacidad ejecutiva, por no representar a la nobleza y al clero, ni haber consultado a las ciudades, lo que legitimaba la desobediencia frente a lo que quedaba reducido a una asamblea de particulares. Los juristas llamados por las Cortes -Cueva, Balboa-, recurrieron a innovadores argumentos de autoridad sobre la legitimidad, en especial que los procuradores de las Cortes ostentaban un oficio público, tenían libre administración y plenos poderes, y formaban un cuerpo de personas representativas, no de las ciudades

${ }^{61}$ Aguilar-Adan, Ch. 2005. «D’une polémique baroque et de ses effets: patronage de l'Espagne et répresentations du corps social, 1616-1631», en P.L. Fournier (ed.) Institutions \& représentations du politique: Espagne, France, Italie, XvII -XXe siècles : 25-43. Paris: Pr. Un. Blaise Pascal. Utiliza la documentación convencional, en especial el legajo 9140 de la BN.

Hispania Sacra, LXVII

136, julio-diciembre 2015, 531-573 ISSN: 0018-215X, doi: 10.3989/hs.2015.016 
sino del Reino, pudiendo tomar iniciativas para todos los estados de la república, entre los que estaba el clero -que era una comunidad particular-. Por otra parte, los projacobeos ponían en causa la legitimidad de la monarquía, por cuanto el rey había tomado partido en lugar de defender el interés general -el de la Iglesia y del Estado- y había entrado en un ámbito de competencia de la Iglesia, pero del lado teresista, la ausencia de consulta al clero se había resuelto por el rey y las Cortes pidiendo licencia al papa y al conseguirla se consideró su causa legitimada. En cuanto a la dimensión territorial del patronato, la decisión de las Cortes respondió a una castellanización de España, arrogándose una representación general, que fue una de las claves de la disidencia de los territorios periféricos: los projacobeos fueron conscientes de esto, recordando a las Cortes que esos territorios tenían sus propios cuerpos representativos, que los demás reinos no estaban afectados por el copatronato, sino que Santiago y la Iglesia eran los únicos representantes de España y los garantes de su unidad cristiana.$^{62}$

Con las mismas fuentes que Aguilar-Adan en 2008, el hispanista inglés I.A.A. Thompson dedicó un artículo al patronato centrado en la cuestión de la autoridad. ${ }^{63}$ Thompson no vincula el segundo episodio con la Unión de Armas, como sugería Elliott, aunque sí la iniciativa a Olivares de anunciarlo estando el rey en Zaragoza, pero el núcleo del artículo es la auto-percepción de España en el mundo, el sentido de la identidad providencialista, la mentalidad de crisis, los conflictos de valores e ideales, los parámetros del discurso político, cultural e intelectual, tanto en la política interior como en asuntos eclesiásticos, las transformaciones en las formas y economía de la devoción, y sobre todo, la cuestión de qué autoridad podía elegir patrón. Al ser propuesta Teresa por las Cortes a petición del rey, con implicaciones espirituales y rituales que necesitaban confirmación papal, se tocaba la relación de los poderes civiles con la jurisdicción eclesiástica, la representación de las Cortes, y los poderes del rey en relación con la supremacía papal. Sin embargo, al haber utilizado la misma documentación que Aguilar-Adan, el desarrollo de estas cuestiones es muy similar. Un aspecto un poco diferente es que los letrados de las Cortes identificaban la beatificación de Teresa con una especie de canonización regional limitada y así se podía justificar por su utilidad pública, lo que hizo intervenir a la Inquisición, y que se debatieron las bases del poder representativo y constitucional, algo sin precedentes. Los teresistas emplearon una teoría innovadora sobre las Cortes que implicaba un concepto elevado de la autoridad del procurador con respecto a la ciudad que representaba, de las ciudades con voto, y de la representatividad del reino en Cortes: no era necesario el acuerdo de las ciudades para nombrar patrones y los poderes que portaban los procuradores

\footnotetext{
${ }^{62}$ En este aspecto, concuerda con lo que, desde otro ángulo, había planteado Teófanes Egido, a quien citaremos.

${ }^{63}$ Thompson, I.A.A. 2008: 293-320. Utiliza el legajo 9140 de la Biblioteca Nacional, las actas de las Cortes de Castilla y otras fuentes conocidas en su mayoría, sin citar apenas a quienes lo precedieron.
} 
eran libres si no iban contra los intereses de sus ciudades, y un acto piadoso no lo era; pero al ser el rey el único que podía autorizar la novedad, los teresistas sostienen una posición absolutista porque no se necesitaba el voto de las ciudades, mientras que los santiaguistas decían que por historia, instituciones y tradiciones jurídicas, la autoridad real estaba limitada por la eclesiástica y la papal, superior en lo espiritual y religioso -las posiciones se invirtieron en las Cortes de Cádiz-. En fin, la polémica fue un conflicto entre autoridades civiles y eclesiásticas, ciudades y Cortes, justicia y costumbre, rey y papa, pero las opiniones manejadas eran convencionales, por cuanto quienes las formularon eran clérigos, letrados o escritores que compartían conceptos y principios jurídicos y políticos como «instrumentos de pleitesía», y fueron adaptando sus posiciones a la evolución de la polémica. No se elaboró una teoría coherente sobre la autoridad sino una gama de ideas, conceptos y argumentos corrientes y disponibles en la sociedad y la cultura del momento: plasticidad, ambivalencia y oportunismo.

Nuestra duda sobre las lecturas de Thompson y Aguilar-Adan es si el tema del patronato tenía envergadura suficiente para dar de sí un fragmento de teoría: a fin de cuentas se estaba decidiendo entre dos santos y en la época las Cortes trataban problemas de más enjundia, como la negociación fiscal, en la que era fundamental fijar el poder de las ciudades representadas en Cortes.

La interpretación en clave política se reforzó en 2009, de un modo más original, con Sandra Chaparro en un artículo sobre cómo pudo una mujer erigirse en un símbolo y qué simbolizaba Teresa en la geopolítica española. La respuesta está para ella en la segunda mitad del XVI, cuando se desarrolló la imagen de las religiosas como vírgenes y santas, humildes y obedientes; Teresa subrayaría la ortodoxia y los estereotipos misóginos oficiales -ignorancia, timidez, debilidad- en una estrategia retórica para disimular su desobediencia y conseguir sus objetivos, pero además, el modelo político de la monarquía católica se basaría en el amor, en una comunidad política justa: símbolos, santos, rituales o metáforas eran aglutinantes en la formación de república de cristianos, para hacer visible la adhesión de la comunidad a las verdades que el ejemplo santo transmite.$^{64} \mathrm{La}$ insistencia de la mística del XVI en la ley del amor, conforma «un nuevo símbolo geopolítico» y la imagen femenina como símbolo de un amor capaz de moldear conductas basadas en la fe, la lealtad, reciprocidad, igualdad o la templanza, tendría en la Virgen su máxima expresión, pero Teresa hace terrenales esas virtudes, y sus fundaciones y su obra habían demostrado su eficacia práctica. Sobre esos antecedentes, Sandra Chaparro, se plantea el aspecto más literario y simbólico -sic- de la polémica del patronato, en la que se opusieron dos ideas sobre lo que debía representar la monarquía católica y el tipo de política que convenía a quienes la dirigían. Para

\footnotetext{
${ }^{64}$ Chaparro Martínez, S. 2012. Providentia: el discurso político providencialista español de los ss. XVI y XVII: 189-190. Madrid: Un. Comillas.

Hispania Sacra, LXVII

136, julio-diciembre 2015, 531-573 ISSN: 0018-215X, doi: 10.3989/hs.2015.016
} 
esto se basa en Su espada por Santiago por cuanto Quevedo subraya la condición de Teresa como beata y mística dada a las revelaciones -aunque fuera doctora y fundadora-, mientras Santiago recuerda a Cristo, como capitán de una iglesia militante. Los devotos de Teresa le atribuían introducir en la monarquía la teología mística, una nueva forma de entender la espiritualidad, más avanzada, exquisita y pacífica, contemplativa pero activa. «Así vista, la polémica adquiere cualidades de una representación pictográfica de virtudes teo-políticas»; Teresa y Santiago eran símbolos de una monarquía católica en una encrucijada: entre paz o guerra, industriosa renovación económica o gasto bélico, evangelización de herejes o espiritualidad -una cosmovisión de realidades alternativas para el pueblo-. Elegir a uno u otra equivalía suscribir los valores y el tipo de orden que simbolizaban: la espada representa la guerra, al príncipe que imparte justicia al servicio de Dios - evangelización, castigo de herejes, restauración del orden- y la paz que surge de la victoria sobre la discordia; la rueca representa el valor del trabajo manual y de la tierra, compatible con el rezo y la meditación, las cosas sencillas y la familia. ${ }^{65}$ De nuevo se minimiza que Santiago fue el vencedor.

Parecería que ya no se podía estirar más el tema, faltando un análisis integrador, y ese fue el objetivo en 2005 de la tesis de Erin K. Rowe, historiadora norteamericana. Rowe emplea materiales en su mayoría conocidos -añade otros- y una bibliografía anglosajona en casi tres cuartas partes, española en cuarto y con pocas referencias a publicaciones francesas e italianas, con ausencias llamativas (Márquez); hace algunas lecturas poco fundamentadas del cartografiado de las fidelidades a Teresa o a Santiago, o de la personalidad de los implicados, y maneja el concepto de nación española de un modo precoz para la época. Es muy valiosa su sistematización de los datos y su interpretación a la luz de las nuevas tendencias en cultura política y en el reciente interés por las santas locales, y desde un objetivo claro: la relación entre santos patronos, esfuerzos de consolidación de la autoridad real y resistencias a las políticas reales.

Rowe juega con la idea de que mientras Felipe IV, los carmelitas y muchos obispos defendieron a Teresa, y se atribuyó al rey la elección de la santa exagerando su interés, el antagonismo pudo originarse de la oposición a Olivares: los opositores a Teresa le atribuían la responsabilidad y los partidarios buscaban congraciarse con él. Para el frente opositor, los dos patronos simbolizaban los peligros de la autoridad plural -el rey y el valido- y la hostilidad a Teresa, lo era a Olivares y al valimiento; en este bando estaban todos los cabildos catedralicios de Castilla, que rechazaron la autoridad real y papal al no celebrar el patronato. ${ }^{66}$

\footnotetext{
${ }^{65}$ Chaparro Martínez, S. 2009. «La rueca y la espada: El patronato de Santa Teresa o la mujer como metáfora política», en P. Pérez Cantó (ed.), De la democracia ateniense a la democracia paritaria: 43-60. Barcelona: Icaria.

${ }^{66}$ Rowe, E.K. 2006: 721-737.
} 
El análisis de los textos a favor y en contra conduce a Rowe a afirmar que detrás de temas litúrgicos y teológicos, los autores abordaron la autoridad papal y real, la libertad eclesiástica, las facciones políticas, el mérito literario, el género y la política exterior -es decir, tensiones propias del xvII-, y que la identificación del culto a Teresa con el gobierno real y su política, derivó en una elevada reflexión sobre la política terrenal -al contrario de la opinión de Márquez y de Thompson-. Por otra parte, Rowe se plantea el papel del patronato nacional en la creación de una identidad cívica, tema poco estudiado por comparación con los santos locales; los patrones nacionales funcionaban como representaciones espirituales con significado simbólico, por eso mismo, en la monarquía hispánica, dada su fragmentación territorial, Teresa adquiría una función aglutinadora para la Corona - en el debate se habla de patrón de España no de Castilla-. El problema surgiría cuando «algunos castellanos» vieron su proclamación como una razón de estado, para preservar y sostener a la monarquía contra enemigos extranjeros, en tanto que sus opositores sostenían que atacar a Santiago -a pesar de estar en descrédito- podría llevar a la destrucción. Como fuere, el patronato adquirió funciones simbólicas e ideológicas alineadas con políticas e intereses específicos y la celebración de Teresa como patrona fue una performance pública de poder real y de unidad.

El desarrollo amplio del tema se hace en Saint and Nation, que Rowe presenta como un case study sobre el papel que la santidad jugaba en la representación simbólica de la nación. ${ }^{67} \mathrm{La}$ obra -siguiendo a varios autores- se estructura en torno a Santiago y su declive, Teresa y su experiencia de santidad; la política del patronazgo; el género y la política exterior; el cartografiado sagrado -ciudades que celebraron el co-patronato y las opuestas-; el rey, la nación y la Iglesia en la monarquía Habsburgo y los problema con Roma. Parte Rowe de que Santiago y Teresa son los santos más icónicos de la «españolidad», de la vida cultural española ${ }^{68}$ pero, quizá por conocer solo parte de la bibliografía, afirma que hay pocos estudios sobre sus roles vitales en el imaginario histórico cultural español. Para Rowe, Teresa significaba un cambio político, espiritual e ideológico que alarmó a los castellanos porque alteraba la comprensión tradicional de la nación española: se interrumpía un relato -el final de la Reconquista, el conflicto religioso intra-europeo o el final de la hegemonía-, y se imponía otro. El gran interés de las elites castellanas en tener una nueva representación espiritual, refleja profundas transformaciones y los cambios que vivía España: las cargas fiscales y las complicaciones morales del Imperio y la cambiante situación política en Europa, generaban inestabilidad de la identidad y una crisis general entre los castellanos.

\footnotetext{
${ }^{67}$ Rowe, E.K. 2011. Saint and Nation: Teresa of Avila, Santiago, and Plural Identities in Early Modern Spain. Penn State Un. Press.

${ }^{68}$ Rowe, E.K. 2006. «The Spanish Minerva: Imagining Teresa of Avila as Patron Saint in SeventeenthCentury Spain», The Catholic Historical Review XCVII-3006: 416-438. 2011.

Hispania Sacra, LXVII

136, julio-diciembre 2015, 531-573 ISSN: 0018-215X, doi: 10.3989/hs.2015.016
} 
Rowe considera demostrado que la batalla entre ambos santos planteó además los acuerdos y desacuerdos entre el monarca y la ciudad, el centro y la periferia, y que las implicaciones intelectuales y políticas que sostuvieron lealtades específicas a los santos, revelan matices en el imaginario de las elites religiosas españolas. La lucha dio pie a un gran debate en panfletos y púlpitos sobre el carácter de España «nación» y el papel de la religión en la construcción de esta, en el que los santos patrones compitieron en la comprensión de los orígenes de España, la geografía sagrada y las aspiraciones políticas en un tiempo de crisis y transición del reino medieval a la nación política moderna. Los escritores imaginaron comunidades empleando términos diferentes para designar a la nación -monarquía española, las Españas, España, Hispania, Corona de Castilla, etc.- y representaron a cada santo con rasgos diferenciadores para definirla: Santiago, era el fundador de la España cristiana y había convertido al pueblo de España a la santidad en los tiempos bíblicos; su popularidad como Matamoros estaba asentada en su ayuda a Castilla en batallas de la Reconquista; la traslación de sus restos a Galicia tras su martirio eran un signo de afinidad y lealtad con la nación; su posición dominante y su patronato se basaban en que representaba la Historia y la nación de España. Este mensaje identifica a los santiaguistas como conservadores, al reclamar la antigüedad como condición clave para el patronato, mientras que los teresianos re-conceptualizaron la nación al priorizar lo moderno: Santiago era un santo viejo para problemas viejos, y Teresa era nueva y contemporánea y por eso ofrecía una guía para los problemas del XVII. Rowe concluye que el debate fue multifacético y reunió las voces de intelectuales, políticos y teólogos de Castilla, mientras que los demás territorios peninsulares no le prestaron atención.

En nuestra opinión, la autora sobrevalora la importancia del debate en sí mismo y en lo que aportó a las definiciones tempranas del carácter de la nación española, con independencia de lo que esto significaba en el primer siglo XVII; Rowe lo da a entender al subrayar que solo Castilla se interesó en el patronato. Si es que Teresa tenía que representar lo que se le atribuye, fue la perdedora y por lo tanto no cumplió la misión que Felipe III y Felipe IV -u Olivares- le encomendaron en la forja de ese carácter. La lectura de Rowe, sin duda interesante, prescinde de aspectos colaterales de gran influencia en el debate y da a los textos y los datos - a veces de un modo algo forzado- un sentido nuevo, pero centrado en una sola dimensión que no logra redondear, sobre todo al pasar por alto las posteriores derivaciones del patronato.

\section{LOS OTROS PATRONATOS DE TERESA}

En efecto, conviene no olvidar los otros patronatos de santa Teresa. El patronato de 1812 apenas ha merecido atención en los estudios sobre las Cortes gaditanas, bien porque no parece un tema relevante en comparación con la elaboración 
de una constitución, o porque una decisión tan piadosa desentona en una asamblea política «revolucionaria» en la que se revisó la relación entre la Iglesia y el Estado. El estudio más completo es el citado artículo de 1980 de Lasa y Laboa que analiza los avatares del patronato hasta el Trienio Liberal, ${ }^{69}$ basándose en el anónimo de 1812, sin entrar a discutirlo, y en documentación de los archivos Secreto Vaticano, de las Cortes e Histórico Nacional. El artículo se detiene en la comisión de 1812, sobre todo en su presidente, Lorenzo Villanueva, ligado al jansenismo liberal, aunque consideran que en la cuestión del patronato no hubo jansenismo sino regalismo, ya que la idea central de Villanueva era la defensa de un derecho adquirido de la Corona. Los autores tildan de intransigente la actitud del gobierno constitucional e informan de los equívocos y actitudes contradictorias entre el papa y Fernando VII, y entre aquel y el gobierno liberal del Trienio.

En 1984 expresamos nuestra opinión de que el patronato de 1812 fue un nuevo episodio de crisis de las tradiciones jacobeas, no en vano una de las decisiones importantes adoptadas por los diputados fue la abolición del Voto de Santiago, tras un durísimo debate que las dejaba muy mal paradas..$^{70}$ Otros autores, pocos, han hecho apreciaciones similares. Así por ejemplo, Morán Ortí opina que los diputados buscaron el apoyo del estamento clerical e hicieron jurar obediencia a cabildos y autoridades para ofrecer una imagen de legalidad y orden en una revolución en la que se adoptaron resoluciones de reforma eclesiástica que afectaban a las convicciones religiosas, convicciones que ellos mismos compartían y que se expresaron en el reconocimiento de la fe católica como oficial; en tal contexto, la proclamación de Teresa gustó a los jansenizantes y sirvió para neutralizar la abolición del Voto, mediante un trámite que equivalía a marcar la entidad de una iglesia nacional. ${ }^{71}$ En cuanto a Vicente Algueró, en su obra sobre el catolicismo liberal (2012), considera que la proclamación de Teresa respondió a un debate «entre católicos tradicionalistas, quienes mantenían una alianza estrecha entre el Trono y el Altar, una influencia basada en la tradición y la ortodoxia, y quienes se inspiraban en algunas ideas filo-jansenistas», esto es, la Iglesia reformada, episcopal y «menos frailuna», y que este fue el grupo que logró imponerse y, entre otras cosas, suprimir el Voto. ${ }^{72}$

Después del Trienio, Santiago volvió al patronato en solitario, pero eso no terminó con la utilización de la santa en patronatos tardíos, tema bien desarrollado por Giuliana di Febo al comparar los tres episodios anteriores con otros vividos durante el franquismo, en especial desde que en 1937 se localizó en Málaga la

\footnotetext{
${ }^{69}$ Lasa Iraola, I. y Laboa Gallego, J.M.: 1980: 265-285.

${ }^{70}$ Rey Castelao, O. 1987. «La crisis de las rentas eclesiásticas en España. El ejemplo del Voto de Santiago», Cuadernos de Investigación Histórica. 11: 53-87.

${ }^{71}$ Morán Ortí, M. 1994. Revolución y reforma religiosa en las Cortes de Cádiz: 18-56. Madrid: Actas, Madrid.

${ }^{72}$ Vicente Alguero, F. de. 2012. El catolicismo liberal en España: 79-80. Madrid: Encuentro. 
perdida mano de Teresa, celebrada con un ritual similar a las apariciones de restos de santos en la edad media. La autora explica e interpreta la designación de Teresa como patrona de la Sección Femenina de la Falange, una idea de Pilar Primo de Rivera puesta en práctica quizá en 1937, «asimilando la misión de fundadora «silenciosa» de la santa carmelitana a la de las mujeres de Falange, «comprometidas en la construcción del Nuevo Estado». ${ }^{73}$ Por su parte, K. Richmond (2004), considera que la adopción de Teresa sirvió para reforzar el mensaje de que la identidad de las mujeres de la Sección era inseparable de la religión, pero también «la interpretación particular de que la identidad de la Sección Femenina difería de la del modelo más habitual, que era el de la Virgen María»; la combinación entre fe y acción práctica, encontraba eco en la Teresa fundadora de conventos, nexo entre el servicio de la Sección y la vida religiosa; la Primo de Ribera gustaba de comparar a las afiliadas con las teresianas, grupo laico con voto religioso para dedicarse a la educación, pero esta interpretación distanció a la Sección de otros grupos confesionales ${ }^{74}$ Desde otra perspectiva, este patronato fue estudiado por Suárez Fernández, que sitúa su origen en el primer consejo de la organización en 1937, cuando parte del episcopado desconfiaba de sus principios: la Sección no reconocía un pasado dinástico sino «núcleos creativos de energía espiritual» para afrontar problemas nuevos que exigían «una revolución en la justicia social» y apoyos sobrenaturales, por lo que Isabel la Católica y Teresa de Avila se convirtieron en «arquetipos, modelos, símbolos y bandera». ${ }^{75}$ Era el punto final de un largo proceso de utilización de la imagen de la santa.

\section{A MODO DE RECOPILACIÓN}

El tema que hemos abordado en estas páginas tiene serias dificultades para estudiarlo si no es en orden cronológico porque mezcla elementos y cuestiones colaterales de no pequeña trascendencia que continúan abiertas, de modo que las líneas finales tendrán forma de pregunta:

\section{¿De dónde fue patrona Santa Teresa?}

El episodio de 1618 se limitó a la Corona de Castilla, pero el breve de 21 de julio de 1627 lo concede «in universa hispaniarum regna», de ahí que se hablara de «patronato de España»; pudo ser un error, como piensan algunos autores, salvo

\footnotetext{
${ }^{73}$ Di Febo, G. 2003. «Nuevo estado, nacionalcatolicismo y género», en G. Nielfa (ed.), Mujeres y hombres en la España franquista: sociedad, economía, política, cultura: 27. Madrid: Ed. Complutense.

${ }^{74}$ Richmond, K. 2004. Las mujeres en el fascismo, la Sección Femenina de la Falange,1934-1959. Madrid: Alianza Ed.

${ }^{75}$ Súarez Fernández, L. 1993. Crónica de la Sección Femenina y Su Tiempo. Madrid: Asociación Nueva Andadura.
} 
que la legación de Felipe IV en Roma hubiera buscado eso intencionadamente. En cuanto a la Corona de Aragón, Felipe IV utilizó Zaragoza como plataforma para iniciar el nuevo patronato, ya fuese o no en relación con la Unión de Armas, pero los territorios aragoneses se mantuvieron al margen, no así en el debate en torno al culto a la Virgen del Pilar de Zaragoza y el culto al Apóstol. No hay duda, sin embargo, de que la dimensión de patrona general la adquirió en las Cortes de Cádiz, ya que los diputados se consideraban representantes «de España».

La aceptación territorial del patronato de Teresa tuvo para los teresianos un interés claro y fue tabulada por primera vez por fray Joaquín de Santa Teresa en 1735 , como ya vimos, contabilizando 34 ciudades y villas con una intención propagandística, y estableciendo una embrionaria cartografía del patronato que luego ha desarrollado Erin Rowe. Los mapas de esta última tienen un interés diferente, tratando de localizar y medir el grado de aceptación de la novedad, pero no tiene en cuenta los mapas de Lidwine Linares sobre la distribución territorial de la imagen del Apóstol -matamoros en el Norte, Castilla, León, Extremadura o Andalucía; evangelizador en el resto-, que tienen una relación estrecha con la aceptación o no del patronato de Teresa. ${ }^{76}$ Por otra parte, Rowe tampoco en cuenta las provincias eclesiásticas, un dato importante porque permitiría ver que entre las diócesis sufragáneas de Santiago - que iban de Galicia a Badajoz- hubo decantaciones diferentes y no hubo un seguimiento a las indicaciones de Compostela, del mismo modo que en otras provincias hubo adhesiones a Santiago sin imposición ajena. Más bien hay que ir al registro histórico y a la creencia en una precoz cristianización por parte del Apóstol, que otorgaba santidad a las ciudades episcopales, a sus instituciones y a sus linajes, en línea con las genealogías colectivas que cuentan con tantos estudiosos.

Desde el punto de vista de las adscripciones territoriales, el hecho de que la sede del patronato de Santiago estuviese en Galicia, no tuvo repercusión más allá de las elites eclesiásticas. En Compostela, el cabildo no comunicó el patronato de Teresa al ayuntamiento, incumpliéndose las órdenes reales, pero en las actas municipales constan las fiestas de 1630 para celebrar la restauración del Apóstol. Igual de significativo es el silencio de las Juntas del Reino de Galicia, reunidas en 1628 y 1629, ya que en esos años negociaban con la Corona la compra del voto en Cortes y la financiación de la escuadra de defensa, poniendo sobre la mesa cien mil ducados y una lista de agravios y reivindicaciones al rey que no incluyen la reposición del patronato del Apóstol. ${ }^{77}$ No es irrelevante este hecho, ya que rebaja el tono político de la polémica y lo devuelve a un asunto religioso.

${ }^{76}$ Linares, L. 2008. «Territoire et représentations. La variété des figures de saint Jacques dans quelques chroniques locales du Siècle d'Or», en F. Delpech (ed.), L'imaginaire du territoire en Espagne et au Portugal (XVI - XVII $e^{e}$ siècles): 127. Madrid: Casa de Velázquez.

${ }^{77}$ Eiras Roel, A. (ed.). 1995. Actas de las Juntas del Reino de Galicia 395. Santiago: Xunta de Galicia. 
Respecto a los territorios italianos, las referencias son escasas y confusas. El anónimo de 1812, basándose en fuentes carmelitas, menciona que Nápoles hizo patrona a Teresa en 1628, pero fray Antonio de San Joaquín en Año teresiano habla de 1664, cuando el Parlamento convocado por el virrey conde de Peñaranda, muy devoto de la santa y favorecedor de sus conventos, habría aclamado a Teresa como patrona y protectora de la ciudad y el Reino, pero en la obra de Diana Carrió sobre el ceremonial napolitano del XVII no constan celebraciones al respecto. ${ }^{78}$

No se sabe mucho más con respecto a América, a pesar de en Cádiz, la propuesta de recuperar el patronato procedió de Guatemala. Consta que se envió la orden de 1618 para celebrarlo o al menos en México, el corregidor presentó al cabildo de la ciudad la orden del rey de jurar el patronato y celebrarlo, de lo que da cuenta Dámaso Alonso..$^{79}$ Más adelante, según fray Severino de Santa Teresa, Carlos II declaró a la Teresa patrona del Darién y mandó a la Real Audiencia de Nueva Granada hacer una fiesta anual. ${ }^{80}$ Sin embargo, L. Cardaillac, en su obra sobre el culto al Apóstol en América, no hace referencia a la repercusión del debate, ni los estudios sobre la literatura jacobea en aquel continente, lo que permite deducir que fue escasa. ${ }^{81}$

\section{¿El patronato de Teresa tuvo repercusión popular?}

En la bibliografía comentada no se duda de que el debate del patronato fue cosa de grupos minoritarios, de la Corte y de provincias, pero no hay la misma unanimidad respecto a la relación entre el cambio de patronato y la religiosidad popular. Américo Castro subrayó en su día la devoción popular al Apóstol, pero el pago del Voto de Santiago lo hacía impopular entre el campesinado, a lo que también colaboraba su imagen bélica, de modo que sufría la competencia de los santos terapeutas y especializados, una dimensión que cuenta con bibliografía reciente. ${ }^{82}$ La popularidad estaría en Teresa, según Teófanes Egido, quien estudió los pronunciamientos religiosos de las Cortes como reflejo del universo de representaciones mentales de los procuradores y estos de Castilla, visible en su funcionamiento sacralizado y en la presencia de agentes contrarreformistas. Para Egido, las Cortes, que habían promocionado a santos terapeutas, canonizaciones por parte de órdenes religiosas, o el culto la Inmaculada -punto de

\footnotetext{
${ }^{78}$ Carrió, D. 2008. El gobierno de las imágenes. Madrid: Iberoamericana.

${ }^{79}$ Alonso, D. 1959. El Fabio de la epístola moral: 52-53. Madrid: Academia de la Historia.

${ }^{80}$ Santa Teresa, F. S. 1956. Historia documentada de la Iglesia de Urabá y el Darién. Victoria: Kelly.

${ }^{81}$ Cardaillac, L. 2002. Santiago Apóstol. El santo de los dos mundos: 162-166. Jalisco: Colegio. Vila Da Vila, M. 1993. «Santiago en la literatura hispanoamericana», en J.Mª Díaz Fernández (dir.), Santiago y América: 200-220. Santiago: Xunta.

${ }^{82}$ Rey Castelao, O. «A tradición xacobea na Epoca Moderna», O Camiño como destino, Santiago, 1999, p. 19. Christian, W. 1991. Religiosidad local en la España de Felipe II: 206-213. Madrid: Nerea.
} 
encuentro entre elites y pueblo-, se implicaron especialmente en el patronato de Teresa porque era popular y sobre todo porque era castellana, de modo que los argumentos para elegirla fueron «castellanistas» y se la eligió para «obligarla» a cumplir como hija de Castilla. ${ }^{83}$

Sin embargo, esa contraposición no es tan clara y, al final, venció el Apóstol, que tenía de su parte el poder visual del Santiago matamoros, imagen militar del patronato difundida por la imprenta en obras ilustradas como Historia del Apóstol de Castellá Ferrer (1610), o en textos litúrgicos, piadosos o jurídicos. Esta dimensión ha sido estudiada por hispanistas -L. Cardaillac, P. Civil- ${ }^{84} \mathrm{e}$ historiadores del Arte, que subrayan su atractivo y su utilidad para la imagen mítica de la monarquía hispánica ${ }^{85}$ sostenida en círculos cortesanos y en el arte de la Contrarreforma, pero también en humildes espacios rurales. Por el contrario, no hubo tiempo para generar un programa de Teresa como patrona -solo se consagra su imagen como escritora, lo que era una novedad-, con salvedades como un cuadro de 1627 del holandés Abraham Van Diepenbeeck, discípulo de Rubens. ${ }^{86}$

Todavía no se ha hecho un estudio sobre la onomástica femenina o sobre las cofradías que surgieron por entonces con advocación de la santa, lo que sí se ha hecho para Santiago, de modo que faltan elementos de juicio para llegar a una conclusión.

\section{¿Fue un debate singular?}

Por supuesto que no lo fue. En la forja de patronos, que cuenta con una interesante bibliografía, ${ }^{87}$ se actuó por descarte: Santiago fue el patrono tradicional después de que en la Edad Media hubiera habido otros a conveniencia de los reyes o por presiones de instituciones influyentes -la iglesia de Toledo, por ejemplo- y después del compatronato de Teresa, estuvo amenazado al poco tiempo por el arcángel San Miguel, por san José, san Genaro, etc., lo que obliga a relativizar todas las teorías sobre la importancia de aquel. No debe olvidarse

\footnotetext{
${ }^{83}$ Egido, T. 2003. «Religiosidad 'popular' y Cortes tradicionales de Castilla», en M Ma.J. Buxó y S. Rodríguez Becerra (eds.), La religiosidad popular: Vida y muerte: 100-105. Madrid. Anthropos.

${ }^{84}$ Civil, P. 1993. «De Saint-Jacques Matamore à Saint-Ignace de Loyola: estratégies de l'image des saints face à l'altérité religiesuse (Espagne, $\mathrm{XVI}^{\mathrm{e}}-\mathrm{XVII}^{\mathrm{e}}$ siècles)», en $\mathrm{A}$. Redondo, Les représentations de l'autre dans l'espace Ibérique et Ibéro-Américain: II, 75. París: Sorbonne. L. Cardaillac, Santiago Apóstol..., ya citado.

${ }^{85}$ Cruz Valdovinos, J.M. 1999. «Santiago, patrón de España», Santiago. La esperanza: 123-139. Santiago: Xunta. Monterroso, J.A. 2004. «A la sombra de Santiago. La afirmación del culto jacobeo y su identificación con la monarquía durante la Edad Moderna», en García Iglesias. 2004: 53-70. Madrid: S.E.C.C.; Portela, F.J. «Santiago miles Christi caballero de las Españas», ib.: 71; Gómez López, C. «El apóstol Santiago y la Corte: mentalidad, imagen y promoción artística», ib.: 87.

${ }^{86}$ Gatter, O. «Saint Teresa of Avila as an Intercesor», pdf en Internet.

${ }^{87}$ Webb, D. 1996. Patrons and defenders. The saints in the italian city states. Londres: Tauris.
} 
tampoco que en paralelo y después de los dos primeros episodios del patronato, se desarrolló el debate sobre el culto a la Inmaculada Concepción, otra polémica barroca que entretuvo a varios de los actores que también participaron en la que nos interesa, como sucedía en torno al Pilar de Zaragoza.

Por otra parte, el caso de Francia, bien conocido gracias sobre todo a JeanMarie Le Gall, es parecido y un poco anterior: en 1577 «se descubrió» la tumba de Saint Denis, que se impuso como patrono a pesar de ser que este supuesto apóstol de los galos enviado por San Juan, era un santo forjado entre los siglos VI y VIII; la conversión de Enrique IV en su milagroso oratorio, redondeó su imagen como patrono de Francia, barriendo a los anteriores, y el debate al respecto tuvo repercusiones en cierto modo similares. ${ }^{88}$

\section{¿Teresa o Quevedo?}

En la opinión de muchos, si Quevedo no hubiera participado en la polémica, esta hubiera sido menos intensa en su momento y más opaca para la posteridad. Cada vez que se han publicado las obras completas del escritor, sobre todo la edición de 1859 Fernández Guerra y la de 1932 de Astrana Marín, se ha reavivado el interés por los memoriales jacobeos de Quevedo. Por esa vía, el tema del patronato cuenta con una bibliografía a mayores que procede de filólogos e historiadores de la literatura, una variante difícil de evaluar desde nuestra perspectiva al priorizar el estilo, la estructura o la eficacia comunicativa por encima del contenido y por estar un tanto al margen de la historiografía especializada en el período de la polémica. ${ }^{89}$ Además, hay una variante vinculada con los congresos jacobeos que emplea los memoriales para subrayar la relación de Quevedo con Galicia, lo que no pasó de ser una circunstancia. ${ }^{90}$ En nuestra opinión, la participación del literato en la polémica obedeció a razones complejas, de la que no es menor su deseo de destacar y de prestigiarse con el previsible éxito de la causa jacobea, y se ha exagerado su papel, sin que restemos importancia a sus textos jacobeos, así como la originalidad de sus ideas.

${ }^{88}$ Le Gall, J-M. 2007. Le mythe de Saint Denis entre Renaissance et Révolution. París : Champ Vallon.

${ }^{89}$ Rey Alvarez, A. 1993. «Los memoriales de Quevedo a Felipe IV». Edad de Oro 12: 257-265. Ettinghausen, H. 1995. «Ideología intergenérica: la obra circunstancial de Quevedo», en S. Fernández Mosquera (ed.), Estudios sobre Quevedo: 225-260. Santiago: Universidad. Azaustre Galiana, A. 2000. «La argumentación retórica en el «Memorial por el patronato de Santiago», de Francisco de Quevedo». Edad de oro 19: 29-64; Alonso Veloso, M.J. 2002. «La estructura retórica del «Memorial por el Patronato de Santiago» de Francisco de Quevedo». Bulletin of Spanish Studies 79-4: 447-464; 2004. «La dispositio de «Su espada por Santiago «de Francisco de Quevedo», en I. Lerner y otros (coords.), Actas del XIV Congreso de la Asociación Int. de Hispanistas: 27-42, II. Nueva York. Candelas Colodrón, M.A. 2008. Quevedo en la polémica del patronato jacobeo. Vigo: Academia del Hispanismo.

${ }^{90}$ Fucelli, A. «La Polemica per il patronato della Spagna in Francisco de Quevedo y Villegas», en Scalia, G. 1985: 345-357. 


\section{¿Cuál fue la repercusión real del debate?}

En las páginas precedentes hemos expuesto el crecimiento del tema del patronato de Teresa, pero en nuestra revisión del problema y de su contexto, llaman la atención determinados silencios. El más significativo es el de las biografías de la santa, tanto las escritas en la época moderna -marcadas quizá por la distancia que los carmelitas pusieron con respecto a la iniciativa del patronato-, o en el siglo XIX -G. Cunningham Graham (1894)- como en la más reciente -Efrén de la Madre de Dios, M. Auclair, A. Weber, G.T.W. Ahlgren, que no mencionan el debate o lo hacen de paso. Solo Joseph Pérez dedicó un capítulo a la gloria póstuma de la santa en el que afirma que con Teresa «España no buscaba afirmar su militancia religiosa», ya que para eso hubiera sido mejor elegir a Ignacio de Loyola o a Francisco Javier -imágenes de la Contrarreforma y de la colonización-, sino que se jugó con su calidad de escritora; pero Pérez apenas se refiere a la polémica del patronato, incluso la minimiza. ${ }^{91}$ Tampoco las celebraciones de centenarios dedicaron atención al tema, como ya hemos indicado. El hecho de que la bibliografía jacobea, en especial la militante, sí se le haya otorgado tiene que ver con la reciente revitalización de las peregrinaciones y de los estudios al respecto.

Si en la literatura sobre Teresa puede entenderse que el patronato no aportó nada a su imagen posterior porque fue vencida por la tradición y por Santiago, el mismo silencio o el tratamiento breve se pueden constatar en biografías de Felipe III y de Felipe IV, incluso en la de Olivares firmada por Elliott. Y es preciso recordar que en el congreso sobre las Cortes de Castilla en la Edad Moderna celebrado en Salamanca en 1987, no se abordó el patronato a pesar de que el tema de las capacidades de las Cortes estaba en pleno debate historiográfico, o que alguno de los autores citados no se refirieron al patronato cuando antes habían tratado esa cuestión política. ${ }^{92}$

En definitiva, consideramos que el tema se ha ido agrandando al ritmo de una bibliografía que ha ido descendiendo al detalle perdiendo la perspectiva global. Esta tendencia se gestó en medios académicos norteamericanos, pero en todo caso, por medio de filólogos e historiadores de la literatura atraídos por Quevedo o por los escritores y géneros menores que se desarrollaron durante la polémica, en lo que quizá tuvo que ver el hecho de que parte de la documentación sobre el tema se conserve en Estados Unidos. Varios historiadores ingleses se han interesado por la cuestión desde el punto de vista político, dimensión compartida por la francesa Aguilar-Adan, la americana E. Rowe y la española S. Chaparro, lo que tiene su origen en la intervención de personajes de la envergadura del conde duque de Olivares o sobre cuestiones de cultura política, de tanto arraigo en la

\footnotetext{
${ }^{91}$ Pérez, J. 2007. Teresa de Ávila y la España de su tiempo: 272-273. Madrid: Algaba eds.

92 Thompson, I.A.A. 1993. Crown and Cortes. Variorum, Hampshire.
} 
historiografía angolosajona. Por todo esto, la bibliografía se ha centrado en el segundo episodio del patronato, cuando se produjeron los debates más interesantes e intensos y con protagonistas se renombre.

Los hispanistas franceses y algunos autores italianos ya citados se han ocupado de temas jacobeos y en ese contexto han abordado los cambios del patronato, pero en general los han situado en una dimensión menor y en relación con la religión y con las relaciones entre el poder y la Iglesia, dando menos relevancia a la faceta política, y sin forzar determinadas lecturas de los textos. Es lo mismo que se puede decir de la bibliografía española, que ha interpretado la polémica como una manifestación de las devociones particulares de los reyes, y de sus validos o ministros, que elevaron a Teresa y la descendieron de su peana, y de la actitud de las Cortes en los diferentes períodos, que actuaron en consecuencia o a la contra, mientras que el papado intervino solo para refrendar decisiones ajenas sin implicarse en algo que era ni era general ni sustancial, sino privativo de un país.

\section{BIBLIOGRAFÍA}

Aguilar-Adan, Ch. 2005. «D’une polémique baroque et de ses effets: patronage de l'Espagne et répresentations du corps social, 1616-1631», en P.L. Fournier (ed.), Institutions \& représentations du politique: Espagne, France, Italie, $\mathrm{XVII}^{e}-\mathrm{XX}{ }^{e}$ siècles : 25-43. Paris: Pr. Un. Blaise Pascal.

Alonso Veloso, M.J. 2002. «La estructura retórica del 'Memorial por el Patronato de Santiago’ de Francisco de Quevedo». Bulletin of Spanish Studies, 79-4:_447-464.

Alonso Veloso, M.J. 2004. «La dispositio de 'Su espada por Santiago’ de Francisco de Quevedo», en I. Lerner y otros (coords.), Actas del XIV Congreso de la Asociación Int. de Hispanistas: 27-42. Nueva York.

Alonso, D. 1959. El Fabio de la epístola moral. Madrid: Academia de la Historia.

Azaustre Galiana, A. 2000. «La argumentación retórica en el 'Memorial por el patronato de Santiago', de Francisco de Quevedo». Edad de oro 19: 29-64.

Barbas Homem, A.P. 2010. Constitucional Documents of Portugal and Spain. Berlin: De Gruyter.

Barrios Aguilera, M. 2011. La invención de los libros plúmbeos. Granada: Universidad.

Barrios Aguilera, M. y García-Arenal, M. (eds.). 2008. ¿La Historia inventada? Los Libros Plúmbeos y el legado sacromontano. Granada: Universidad.

Bennassar, B. 1970. Saint-Jacques-de-Compostelle. París: Juliard.

Boyer, J. 1945. L 'Aspect littéraire de la querelle au sujet du patronal de l'Espagne: saint Jacques ou sainte Thérése. París : Sorbonne, inédito. 
Braum, D.L. 1970. Traditionalism in the works of Francisco de Quevedo y Villegas. Chapell Hill: Un. North Carolina.

Burgos Hervás, L. 1998. «Felipe II y las reliquias del Apóstol Santiago», Iacobus: 5-6: 83-116.

Caminero, J. 1984. Víctima y Verdugo: conservadurismo y antisemitismo en Quevedo (Problemata semiótica). Kassel: Reichenberger ed.

Candelas Colodrón, M.A. 2006. «Quevedo contra Balboa: «un contraste de diamante», Revista de Erudicion y Crítica 1: 83-90.

Candelas Colodrón, M.A. 2006. «Los escritos de Balboa de Morgovejo y Fray Pedro de la Madre de Dios en «Su espada por Santiago» de Quevedo». Nueva revista de filología hispánica, 54-1: 191-207.

Candelas Colodrón, M.A. 2007. «Los escritos del Arzobispo de Santiago, de Fray Pedro de la Madre de Dios y el papel titulado «Justa cosa, ha sido elegir por patrona de España y admitir por tal a Santa Teresa» en el «Memorial por el patronato de Santiago» de Quevedo», Boletín de la Biblioteca de Menéndez Pelayo. 83: 111-128.

Candelas Colodrón, M.A. 2008. Quevedo en la polémica del patronato jacobeo. Vigo: Academia del Hispanismo.

Cardaillac, L. 2002. Santiago Apóstol. El santo de los dos mundos. Jalisco: Colegio.

Carrió, D. 2008. El gobierno de las imágenes. Madrid: Iberoamericana.

Carro García, J. 1947. «Santiago Apóstol. Patrón de las Españas», Spes 151: 13-24.

Castro, A. 1958. Santiago de España. Buenos Aires: Emecé ediciones.

Castro, A. 1962. La realidad histórica de España. México: Porrúa.

Cerdán, F. 1984. «Santa Teresa en los sermones del Patronato (1627)», en M. Criado (ed.), Santa Teresa y la literatura mística hispánica: 601-608. Madrid: EDI6.

Chaparro Martínez, S. 2009. «La rueca y la espada: El patronato de Santa Teresa o la mujer como metáfora política», en P. Pérez Cantó (ed.), De la democracia ateniense a la democracia paritaria: 43-60. Barcelona: Icaria.

Chaparro Martínez, S. 2012. Providentia: el discurso político providencialista español de los ss. XVI y XVII. Madrid: Un. Comillas.

Christian, W. 1991. Religiosidad local en la España de Felipe II. Madrid: Nerea.

Civil, P. 1993. «De Saint-Jacques Matamore à Saint-Ignace de Loyola: stratégies de l'image des saints face à l'altérité religieuse (Espagne, $\mathrm{XVI}^{\mathrm{e}}-\mathrm{XVII}{ }^{\mathrm{e}}$ siècles)», en $\mathrm{A}$. Redondo, Les représentations de l'autre dans l'espace Ibérique et Ibéro-Américain: II, 75. París: Sorbonne.

Cruz Valdovinos, J.M. 1999. «Santiago, patrón de España», Santiago. La esperanza: 123-139. Santiago: Xunta.

Di Febo, G. 1987. La Santa de la Raza. Un culto barroco en la España franquista. Barcelona: Icaria. 
Di Febo, G. 1988. 2012. Ritos de guerra y de victoria en la España franquista. Valencia: Universidad.

Di Febo, G. 1989. «Per uno Studio sul terzo centenario della morte di Teresa de jesús». Teresianum 40: 491-515.

Di Febo, G. 2003. «Nuevo estado, nacionalcatolicismo y género», en G. Nielfa (ed.), Mujeres y hombres en la España franquista: sociedad, economía, política, cultura: 19-44. Madrid: Ed. Complutense.

Díaz Fernández, J.M. 1995. «Francisco de Quevedo y el cabildo compostelano», en S. Fernández Mosquera (ed.), Estudios sobre Quevedo: 105-118. Santiago: Universidad.

Egido, T. 2003. «Religiosidad 'popular' y Cortes tradicionales de Castilla», en M M J. $^{\text {a }}$ Buxó y S. Rodríguez Becerra (eds.), La religiosidad popular: Vida y muerte: 96-110. Madrid. Anthropos.

Eiras Roel, A. (ed.). 1995. Actas de las Juntas del Reino de Galicia. Santiago: Xunta de Galicia.

Elliott, J.H. 1986. The Count-Duke of Olivares. Yale U.P.

Ettinghausen, H. 1995. «Ideología intergenérica: la obra circunstancial de Quevedo», en S. Fernández Mosquera (ed.), Estudios sobre Quevedo: 225-260. Santiago: Universidad.

Fernández Mosquera, S. 2009. «Quevedo, Galicia y Santiago: una relación tópica y de conveniencia», en J. Álvarez Barrientos y otros (coords.), En buena compañía: 265276. Madrid: CSIC.

Fernández-Guerra, A. 1859. Obras de Don Francisco de Quevedo y Villegas. Madrid: B.A.E.

Feros, A. 2004. «Por Dios, por la patria y el rey: el mundo político en tiempos de Cervantes», A. Feros y J.E. Gelabert (dirs.), España en tiempos del Quijote. Madrid: Taurus.

Filgueira Valverde, J. 1924-25: «Nuevos documentos para la historia del patronato jacobeo», Boletín de la Real Academia Gallega XIX: 189-318.

Ford, R. 2008. Manual para viajeros por España y lectores en casa. Madrid: Turner Publications.

Fucelli,A. 1985. «La Polemica per il patronato della Spagna in Francisco de Quevedo y Villegas», en G. Scalia, Il Pellegrinaggio a Santiago de Compostela e la letteratura jacopea: 345-357. Perugia: Centro It. di Studi Compostellani.

Gatter, O. «Saint Teresa of Avila as an Intercesor», pdf en Internet.

Gómez Centurión, J. 1916. Relaciones biográficas inéditas de Santa Teresa de Jesús ...dados á conocer con motivo del centenario de su natalicio, Madrid: Real Academia de la Historia. 
Gómez López, C. «El apóstol Santiago y la Corte: mentalidad, imagen y promoción artística», en M. García Iglesias (coord.), Santiago y la monarquía de España (15041788): 87-100. Madrid: SECC.

González López, E. 1967. «Cervantes y el patronato único del Apóstol Santiago», Grial 17: 365-369.

Gutiérrez, C.M. 1992. La espada, el rayo... Quevedo y los campos literario y de poder. Indiana: Purdue U.P.

Herbers, K. 1999. Política y veneración de los santos en la Península Ibérica. Desarrollo del Santiago político. Poio: Fund. Cult. Rutas del Románico.

Iglesias Ortega, A. 2000. «Pedro Fernández de Navarrete, un riojano en la catedral de Santiago». Berceo 138: 91-137.

Kendrick, T.D. 1960. Saint James in Spain. Londres: Methuen.

Lasa Iraola, I. y Laboa Gallego, J.M. 1980. «Santa Teresa de Jesús patrona de España en las Cortes de Cádiz». Hispania Sacra 32: 265-285.

Le Gall, J-M. 2007. Le mythe de Saint Denis entre Renaissance et Révolution. París : Champ Vallon.

Linares, L. 2008. «Territoire et représentations. La variété des figures de saint Jacques dans quelques chroniques locales du Siècle d'Or», en F. Delpech (ed.), L'imaginaire du territoire en Espagne et au Portugal (XVI $-X V I I^{e}$ siècles): 123-135 Madrid: Casa de Velázquez.

López Alsina, F. 1999. «Cabeza de oro refulgente de España: los orígenes del patronato jacobeo sobre el Reino asturiano», en J.I. Ruiz de la Peña, Las peregrinaciones a Santiago de Compostela y San Salvador de Oviedo en la Edad Media: 27-36. Oviedo: C. de Educación.

López Estrada, F. 1982. Fiestas por Santa Teresa de Jesús en Málaga y en Antequera (1618 y 1627). Antequera: Caja de Ahorros.

López Estrada, F. 1984. «Cohetes para Teresa: la relación de 1627 sobre las fiestas de Madrid por el Patronato de España de Santa Teresa de Jesús y la polémica sobre el mismo», en T. Egido (ed.), Congreso internacional Teresiano: 654-670. Salamanca: Universidad.

López Ferreiro, A. 1902. Historia de la S.A.y M.Iglesia de Santiago. Santiago: Seminario.

López López, R.J. 1992. «El Camino de Santiago en la Edad Moderna». Compostellanum: 46: 463-483.

López, F.A. 1947. Nuevos Estudios histórico-críticos acerca de Galicia. Madrid: CSIC.

Maravall, J.A. 2001. Estudios de historia del pensamiento español. Madrid: Ed. de Cultura Hispánica. 
Márquez Villanueva, F. 2004. Santiago, la trayectoria de un mito. Barcelona: Eds. Bellaterra.

Martínez Ruiz, E. 2010. La Iglesia de España contra Napoleón. Madrid: Actas.

Mestre Sanchís, A. 2002. «Nueva Dinastía e Iglesia», en P. Fernández Albaladejo, Dinastía y memoria de nación en la España del siglo XviIr: 549-56. Madrid: Pons y Casa de Velázquez.

Moner, M. 2005. «Le prix de la sainteté», en Ch. Couderc y B. Pellistrandi (eds.), Por discreto y por amigo: 121-130. Madrid: Casa de Velázquez.

Monterroso, J.A. 2004. «A la sombra de Santiago. La afirmación del culto jacobeo y su identificación con la monarquía durante la Edad Moderna», en M. García Iglesias (coord.), Santiago y la monarquía de España (1504-1788): 53-70. Madrid: SECC.

Morán Ortí, M. 1994. Revolución y reforma religiosa en las Cortes de Cádiz. Madrid: Actas, Madrid.

Muñoz Sánchez, J.M. 1968. Santa Teresa, síntesis de su vida. Sus patronazgos. Avila: s.i.

Nieto Alcalde, V. y García Morales, M.V. 2004. «Santiago y la monarquía española: orígenes de un mito de Estado», en J. M. García Iglesias (coord.), Santiago y la monarquía de España (1504-1788): 33-51. Madrid: SECC.

Palomares, J.M. 1981. «La política española y su reflejo en las Ofrendas al Apóstol Santiago», Cuadernos de Estudios Gallegos 32: 217-264.

Patronato de Santa Teresa de Jesús a favor de las Españas acordado por las Cortes Generales y extraordinarias el 27 de junio de 1812. Cádiz: Manuel Ximénez.

Pérez, J. 2007. Teresa de Avila y la España de su tiempo. Madrid: Algaba eds.

Péricard-Méa, D. 2000. Compostelle et cultes de Saint Jacques au Moyen Age. París: PUF.

Péricard-Méa, D. 2011. Le Matamore. Mythe, images et réalités. Cahors: La Louve éditions.

Portela, F.J. «Santiago miles Christi caballero de las Españas», en M. García Iglesias (coord), Santiago y la monarquía de España (1504-1788): 71-86. Madrid: SECC.

Rey Álvarez, A. 1993. «Los memoriales de Quevedo a Felipe IV». Edad de Oro 12: 257-265.

Rey Castelao, O. 1985. «La renta del Voto de Santiago y las instituciones jacobeas», Compostellanum 3-4: 323-368.

Rey Castelao, O. 1985. La historiografía del Voto de Santiago. Recopilación crítica de una polémica histórica. Santiago: Universidad.

Rey Castelao, O. 1987. «La crisis de las rentas eclesiásticas en España. El ejemplo del Voto de Santiago», Cuadernos de Investigación Histórica. 11: 53-87. 
Rey Castelao, O. 1988. «La monarquía y la Iglesia de Santiago», en J. Ma Díaz (ed.). Los Reyes y Santiago: 43-58. Santiago: Xunta.

Rey Castelao, O. 1993. El Voto de Santiago. Claves de un conflicto, Santiago: Xunta.

Rey Castelao, O. 1999. «A Coroa e a igrexa de Santiago», en J.M. Díaz (ed.), Santiago e a Esperanza: 34-36. Santiago: Xunta.

Rey Castelao, O. 1999. «A tradición xacobea na Época Moderna», O Camiño como destino, Santiago: Xunta.

Rey Castelao, O. 2004. «Le Chemin de Saint-Jacques à l'Époque moderne. Une revisión». Revue d'Histoire de l'Eglise de France 224: 109-130.

Rey Castelao, O. 2007-8. «La disputa del patronazgo de la Monarquía: ¿Santiago o Santa Teresa?», en J. Martínez Millán y M.A. Visceglia (edts.), La Monarquía de Felipe III: la Casa del Rey: 227-246, I. Madrid: Fund. Mapfre.

Rey Castelao, O. 2008. Los mitos del Apostol Santiago. Vigo: Nigratrea.

Richmond, K. 2004. Las mujeres en el fascismo, la Sección Femenina de la Falange,1934-1959. Madrid: Alianza Ed.

Rodríguez, I. 1972. Santa Teresa de Jesús y la espiritualidad española. Madrid: CSIC.

Rowe, E.K. 2006. «St. Teresa and Olivares: Patron Sainthood, Royal Favorites, and the Politics of Plurality in Seventeenth-Century Spain». Sixteenth Century Journal 37-3: 721-737.

Rowe, E.K. 2006. «The Spanish Minerva: Imagining Teresa of Avila as Patron Saint in Seventeenth-Century Spain», The Catholic Historical Review XCVII-3006: 416-438.

Rowe, E.K. 2011. Saint and Nation: Teresa of Avila, Santiago, and Plural Identities in Early Modern Spain. Penn State Un. Press.

Rucquoi, A. 2007. «Clavijo: Saint Jacques Matamore», Compostelle. Cahiers d'Études 10: 48-58.

San Joaquín, F.A. 1735. Año Teresiano, Diario Histórico, tomo II. Madrid: imp. de Manuel Fernández.

San José, F.J. 1637. Historia del Carmelo descalzo: 191 y 275. Madrid: Francisco Martínez.

Santa Teresa, F.S. 1956. Historia documentada de la Iglesia de Urabá y el Darién. Victoria: Kelly.

Santa Teresa, S. 1915. «El patronato de Santa Teresa en las Cortes de Castilla de 1617». Monte Carmelo 16: 300-304.

Santos Fernández, C. 2003. «Génesis de un impreso salmantino del siglo XVII en defensa del Patronato de Santiago: la defensión apologética de Juan Salgado de Araújo». Compostellanum: 615-671. 
Santos Fernández, C. 2004. «Correspondencia entre los cabildos catedralicios de Astorga y Santiago en torno al copatronato de Santa Teresa (1627-1632)». Astorica 23: 105-144.

Santos Fernández, C. 2004. «Impresos en defensa del Patronato de Santiago: el memorial de fray José González de Villalobos a Felipe IV». Pliegos de Bibliofilia 25: $17-31 ; 2003$.

Santos Fernández, C. 2004. Impresos en torno al patronato de Santiago, siglo XVII. Santiago: Xunta.

Santos Fernández, C. 2008. «Pesquisas realizadas en Sevilla para identificar al autor y al impresor de la contradicción a la carta del arzobispo Pedro de Castro en defensa del Patronato de Santiago», Historia, instituciones, documentos 35: 321-353.

Sicart, A. 1982. «La iconografía del Santiago ecuestre en la Edad media», Compostellanum 28: 11-32.

Sicart, A. 1985. «La figura de Santiago en los textos medievales», en G. Scalia, Il Pellegrinaggio a Santiago de Compostela e la letteratura jacopea: 271-285. Perugia: Centro It. di Studi Compostellani.

Súarez Fernández, L. 1993. Crónica de la Sección Femenina y Su Tiempo. Madrid: Asociación Nueva Andadura.

Tellechea, I. 1958. «Una letanía de santa Terea prohibida por la Inquisición». Espiritualidad carmeliticiae, 9: 458-466.

Thompson, I.A.A. 1993. Crown and Cortes. Variorum, Hampshire.

Thompson, I.A.A. 2008. «La cuestión de la autoridad en la controversia sobre el Patronato de Santa Teresa de Jesús», en J. Aranda Pérez y J.D. Rodrigues, De Re publica Hispaniae: 293-320. Madrid: Sílex.

Vicente Alguero, F. de. 2012. El catolicismo liberal en España. Madrid: Encuentro.

Vila Da Vila, M. 1993. «Santiago en la literatura hispanoamericana», en J.Mª Díaz Fernández (dir.), Santiago y América: 200-220. Santiago: Xunta.

Vivar, F. 2002. Quevedo y su España imaginada. Madrid: Visor libros. Tauris.

Webb, D. 1996. Patrons and defenders. The saints in the italian city states. Londres: 